\title{
ZARYS ROZWOJU TURYSTYKI W REGIONIE LÓDZKIM
}

\author{
Outline of tourism development in the Lódź region
}

\author{
BOGDAN WŁODARCZYK*(iD)
}

\begin{abstract}
Zarys treści. W artykule zaprezentowano najistotniejsze aspekty rozwoju turystyki w regionie łódzkim na tle najważniejszych okresów w rozwoju tego zjawiska w Polsce. Szczególną uwagę skupiono na ostatnich stu latach, w ciągu których w podziale administracyjnym kraju funkcjonowała jednostka o nazwie „,województwo łódzkie”. Dokonano także periodyzacji rozwoju zjawiska i scharakteryzowano wyróżnione okresy, wskazując na ich znamienne cechy.

Slowa kluczowe: historia turystyki, Polska Środkowa, województwo łódzkie
\end{abstract}

\begin{abstract}
The article presents the most important aspects of tourism development in the Łódź region against the background of the most important periods in the development of this phenomenon in Poland. Particular attention has been focused on the last one hundred years, during which the Łódź Voivodeship has existed within the administrative division of the country. The development of the phenomenon was also periodised, and the distinguished periods were characterised, indicating their characteristic features.
\end{abstract}

Keywords: history of tourism, Central Poland, Łódź Voivodeship

\section{Wstęp}

Polska Środkowa na tle innych regionów kraju (w tym także turystycznych) nie wyróżnia się wyraźną specyfiką związaną z rozwojem turystyki. Pomimo swego centralnego położenia i dobrej dostępności komunikacyjnej obszar ten nie cechuje się wybitnym w skali kraju poziomem atrakcyjności turystycznej. Nie było to jednak przeszkodą, aby na terenie województwa łódzkiego rozwijała się aktywność turystyczna, zarówno postrzegana w kategoriach ruchu turystycznego, jak i związana z instytucjonalnym aspektem tego zjawiska. Podobnie jak w innych regionach Polski stanowiła ona odbicie potrzeb i możliwości organizacyjnych w różnych okresach, ale była również inspirowana wydarzeniami o charakterze lokalnym, regionalnym i ogólnopolskim, które często stawały się kamieniami milowymi w rozwoju turystyki nie tylko w omawianym regionie, lecz również poza nim.

Środowisko przyrodnicze regionu łódzkiego, mające charakter przejściowy między pasami nizin na północy i wyżyn na południu, charakteryzuje się dość dużym zróżnicowaniem ukształtowania terenu i rozwiniętą siecią hydrograficzną. Cały region wydaje się figurą opisaną na trójkącie wyznaczonym przez doliny trzech największych rzek tego obszaru, tj. Pilicy, Warty i Bzury.

Pod względem historycznym województwo łódzkie jest także regionem pogranicznym, gdyż jego terytorium składa się z peryferyjnych obszarów zachodniego Mazowsza, południowo-wschodniej Wielkopolski oraz północnych fragmentów Małopolski i Śląska (Koter i in. 2002).

Celem niniejszego opracowania jest przedstawienie zarysu najważniejszych kierunków rozwoju turystyki w Polsce Środkowej - w regionie na potrzeby artykułu utożsamianym z obszarem obecnego województwa łódzkiego. Opracowanie to ma charakter przeglądowy i jest oparte na wielu pracach na temat rozwoju aktywności turystycznej w granicach współczesnego województwa łódzkiego. W artykule wykorzystano m.in. publikacje Liszewskiego (1987, 1991), Matczaka (1984, 1986, 1987, 1994), Wojciechowskiej (1998, 2018), Wilusia (1997), Makowskiej-Iskierki (2011) i Włodarczyka (1999, 2009). Ważnym źródłem wiedzy okazała się także trzecia część „Studium wiedzy o regionie łódzkim" pod redakcją S. Liszewskiego, wydana w roku 1995 przez Łódzkie Towarzystwo

\footnotetext{
* Uniwersytet Łódzki, Wydział Nauk Geograficznych, Instytut Geografii Miast i Turyzmu, ul. Kopcińskiego 31, 90-142 Łódź; e-mail: bogdan.wlodarczyk@geo.uni.lodz.pl, ORCID: https://orcid.org/0000-0003-4744-5886
} 
Naukowe. Literaturę naukową doskonale uzupełniają opracowania popularno-naukowe $\mathrm{i}$ naukowe, z których wymienić należy m.in. publikacje Słoniewskiego (2012), Słoniewskiego i Czestnych (2014), Kobalczyka (2017a, b) oraz Śledzińskiej (2009). Część zaprezentowanych w artykule informacji jest wynikiem wnikliwych obserwacji autora oraz jego ponad trzydziestoletniego doświadczenia w pracy związanej z turystyką.

Biorąc pod uwagę rozwój turystyki polskiej, jak również specyficzne realia związane z położeniem i historią obszaru Polski Środkowej, można następująco speriodyzować dzieje aktywności turystycznej w województwie łódzkim:

- do końca XVIII w.;

- wiek XIX i początek XX w. do 1918 r.;

- dwudziestolecie międzywojenne i II wojna światowa;

- okres państwa socjalistycznego (lata 19451989);

- okres po 1989 r., podzielony na dwa podokresy: do przełomu wieków XX i XXI i po $2000 \mathrm{r}$.

$\mathrm{W}$ podziale tym opisano najważniejsze - zdaniem autora - fakty i wydarzenia, które zadecydowały lub nadal decydują o turystyce w regionie łódzkim.

\section{Okres do końca XVIII w.}

Migracje, które w świetle obowiązujących współcześnie definicji, spełniałyby kryteria nazwania ich turystycznymi, obserwowane były na terenie obecnego województwa łódzkiego jeszcze na długo przed tym, jak zaczęto używać pojęć „turystyka”, „turysta” i ,aktywność turystyczna”. Można do nich zaliczyć np. polowania królów i carów (m.in. Władysława Hermana, Kazimierza Wielkiego, Władysława Jagiełły, Zygmunta Augusta, Stefana Batorego), które odbywały się w dawnej Puszczy Pilickiej, w okolicach Piotrkowa, Wolborza i Spały. $\mathrm{O}$ tym, że teren ten cieszył się powodzeniem jako miejsce letniego wypoczynku, świadczą także zachowane późniejsze letnie rezydencje biskupów (m.in. w Wolborzu i Skierniewicach).

Jednak pierwsze obiekty, w których można było zanocować, powstawały przy traktach i przeprawach przez największe w regionie rzeki (Pilicę, Wartę, Bzurę), m.in. w Spale, Nagórzycach i Sobocie (Baranowski 1979). Karczmy świadczące też usługę noclegową powstawały także przy traktach handlowych i w najważniejszych miejscowościach (np. w Łęczycy, Piotrkowie Trybunalskim, „,rolniczej” Łodzi), gdzie obsługiwały głównie kupców i chłopów przybywających do miasta na jarmarki. Na podstawie mapy reprodukowanej w pracy Kossmana pt. „Śladami dawnej Łodzi” można stwierdzić, że na rynku (współcześnie: Stary Rynek) na wysokości dzisiejszej ulicy Kościelnej, na narożu usytuowana była karczma (Milewska, Włodarczyk 2005).

W 1591 r. w Łodzi powstał szpital-hospicjum, służący jako dom dla przyjezdnych podejmowanych przez włodarzy miasta. Obiekt ten pełnił nie tylko funkcję szpitala, ale i domu noclegowego czy zajazdu wyższej kategorii (Milewska, Włodarczyk 2005).

W XVIII w. w Piotrkowie Trybunalskim ze względu na liczne zjazdy i trybunały powstawało wiele zajazdów. W trakcie tych wydarzeń w większości posesji na starym mieście można było skorzystać z noclegu i wyżywienia. Jak podają cytowani autorzy (Milewska, Włodarczyk 2005), w 1760 r. w Czarnożyłach, osadzie położonej w pobliżu Wielunia, funkcjonował Kafenhaus obsługujący miejscowych oficjalistów.

\section{Wiek XIX i początek XX w. (do 1918 r.)}

Okres XIX w. to zmiany związane z czasem zaborów (region znajdował się obrębie czterech guberni zaboru rosyjskiego) oraz wpisaniem Łodzi (nie będącej stolicą żadnej guberni) pod koniec XVIII w. na listę miast rządowych (1792 r.).

Jako miejsce letniej rezydencji, na mapie turystycznej regionu zaistniała wówczas Spała, w której car Aleksander III wybudował pałac oraz hotele Savoy i Bristol. Car regularnie co dwa lata odwiedzał tę miejscowość, a ostatnie polowanie w 1912 r. odbył tam Mikołaj II (Słoniewski 2012; Słoniewski, Czestnych 2014; Kobalczyk 2017b).

Połowa XIX wieku to także rozwój zajazdów poczty konnej, które powstały m.in. w Łowiczu, Sieradzu, Rokicinach czy Kołacinku. W tym czasie Łowicz ze względu na wielkość miejscowości i pełnione funkcje (stolica księstwa na prawach miasta wojewódzkiego) dysponował dodatkowo czterema hotelami i trzema zajazdami (Milewska, Włodarczyk 2005).

Gwałtowny rozkwit Łodzi przemysłowej stał się przyczyną rozwoju infrastruktury, która mała w założeniu obsługiwać osoby przyjeżdżające do miasta głównie w celach biznesowych. Do pierwszych tego typu obiektów można zaliczyć wybudowany przy Nowym Rynku 9 w 1824 r. szynk z zajazdem oraz „Paradyż” (1829 r.) przy ulicy Piotrkowskiej 175 - oba wystawione przez Jana Adamowskiego. Pierwszy obiekt przypominający 
współczesne hotele wybudowano w Łodzi w 1853 r. Był to „Hotel Polski” (nazywany też z języka francuskiego „, Hotel de Pologne”), założony jako zajazd przy ulicy Piotrkowskiej 3. Jego właścicielem był Antoni Engel. W 1888 r. w wyniku przebudowy zajmującego szerokość dwóch działek domu z 1872 r., należącego do Edwarda Haentschla, przy ulicy Piotrkowskiej 72 powstał hotel „Grand”. Był to wówczas najbardziej elegancki obiekt noclegowy w mieście (fot. 1, rys. 1) (Milewska, Włodarczyk 2004).

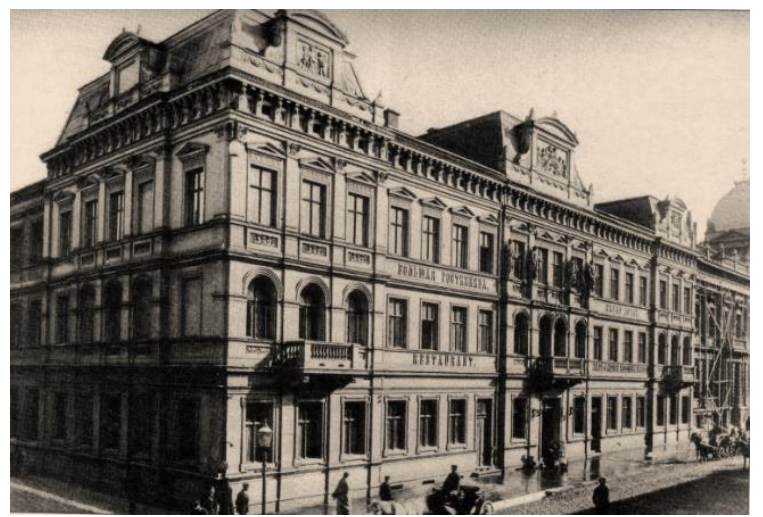

Fot. 1. Hotel „Grand” w Łodzi - koniec XIX w. (Milewska, Włodarczyk 2004))

The Grand Hotel in Łódź - end of the 19th century (Milewska, Włodarczyk 2004)

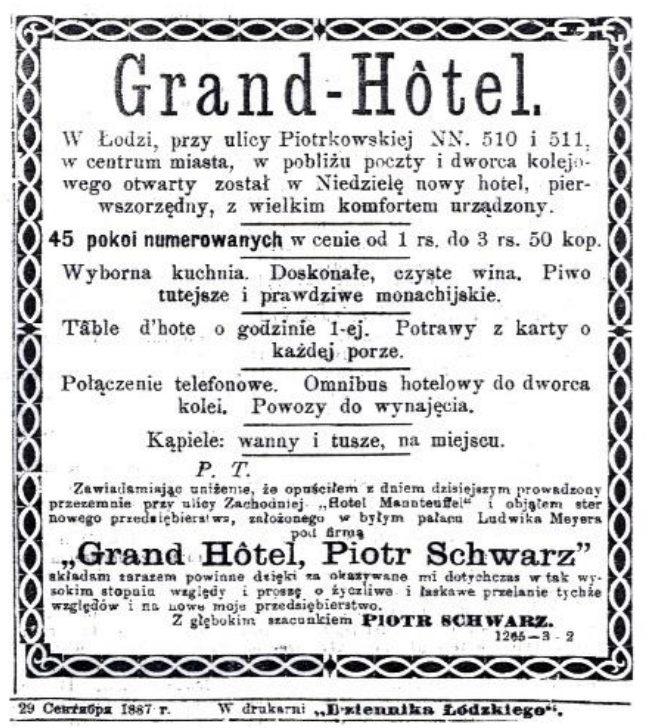

Rys. 1. Ulotka reklamowa hotelu „Grand” w Łodzi (Materiały Archiwum Miasta Łodzi)

Advertising leaflet of the Grand Hotel in Łódź (materials Archive of the City of Lodz)

Koniec XIX w. to także rozwój miejscowości o charakterze stacji klimatycznych, położonych zazwyczaj w otoczeniu suchych lasów sosnowych, których w regionie było pod dostatkiem. W tym czasie powstała m.in. stacja klimatyczno-leśna w Inowłodzu (fot. 2). Podobne działania były podejmowane także w innych miejscowościach Polski Środkowej, m.in. w Gustku i Nagórzycach (obecnie dzielnice Tomaszowa Mazowieckiego), Zakościelu, Teofilowie, Gomunicach, Kolumnie, Głownie czy Tuszynie (Kobalczyk 2017a). Te i inne miejscowości pełniące funkcje wypoczynkowe cechowały się charakterystyczną drewnianą zabudową w stylu nazywanym czasem ,świdermajer" (tj. budowle o lekkiej konstrukcji i z bogato zdobionymi pawilonami, inspirowanymi warszawską Wystawą Rolno-Przemysłową z 1885 r.).

Opisywany okres to także początek rozwoju turystyki w wymiarze instytucjonalnym. Impulsem do podejmowanych działań było powstanie w 1906 r. w zaborze rosyjskim Polskiego Towarzystwa Krajoznawczego (PTK), którego jednym z założycieli był A. Janowski. W pierwszej dekadzie XX w. w Łowiczu, Piotrkowie Trybunalskim i Łodzi utworzono oddziały towarzystwa, a równolegle z nimi powstawały muzea krajoznawcze m.in. w dwóch pierwszych wymienionych miastach. Do najbardziej zasłużonych działaczy turystycznych tego okresu zaliczyć można M. Rawitę-Witanowskiego działającego w Piotrkowie (fot. 3) oraz J. Czeraszkiewicza - obecnie patrona oddziału łódzkiego PTTK (fot. 4) (Śledzińska 2009).

W tym samym czasie zaczęły wychodzić pierwsze przewodniki turystyczne po regionie łódzkim (rys. 2). Organizowane wówczas przez oddziały PTK wycieczki w większości miały nie tylko poznawczy, ale także patriotyczny charakter. Siedziba oddziału łódzkiego mieściła się przy ul. Piotrkowskiej. Skupiał on sekcję muzealną, odczytową i wycieczkową, a w późniejszym czasie także fotograficzną i statystyczną. Przy oddziale funkcjonowała również biblioteka, która w 1918 r. liczyła prawie 500 książek (Historia Oddziału Łódzkiego... 2019).

Opisywany okres charakteryzował się stałym rozwojem aglomeracji łódzkiej i rosnącym zapotrzebowaniem na tereny rekreacyjne, potrzebą wypoczynku oraz zwiększeniem dostępności terenów podmiejskich. Dostępność ta poprawiła się w związku z wybudowaniem w 1866 r. drogi kolejowej między Łodzią a koleją warszawsko-wiedeńską oraz oddaną do użytku w 1903 r. tzw. koleją kaliską, łączącą Łódź i Warszawę. Poprawa dostępności komunikacyjnej (w tym także nowe linie tramwajów podmiejskich) sprawiły, że w tym czasie również dynamicznie rozwijały się letniska podmiejskie. 

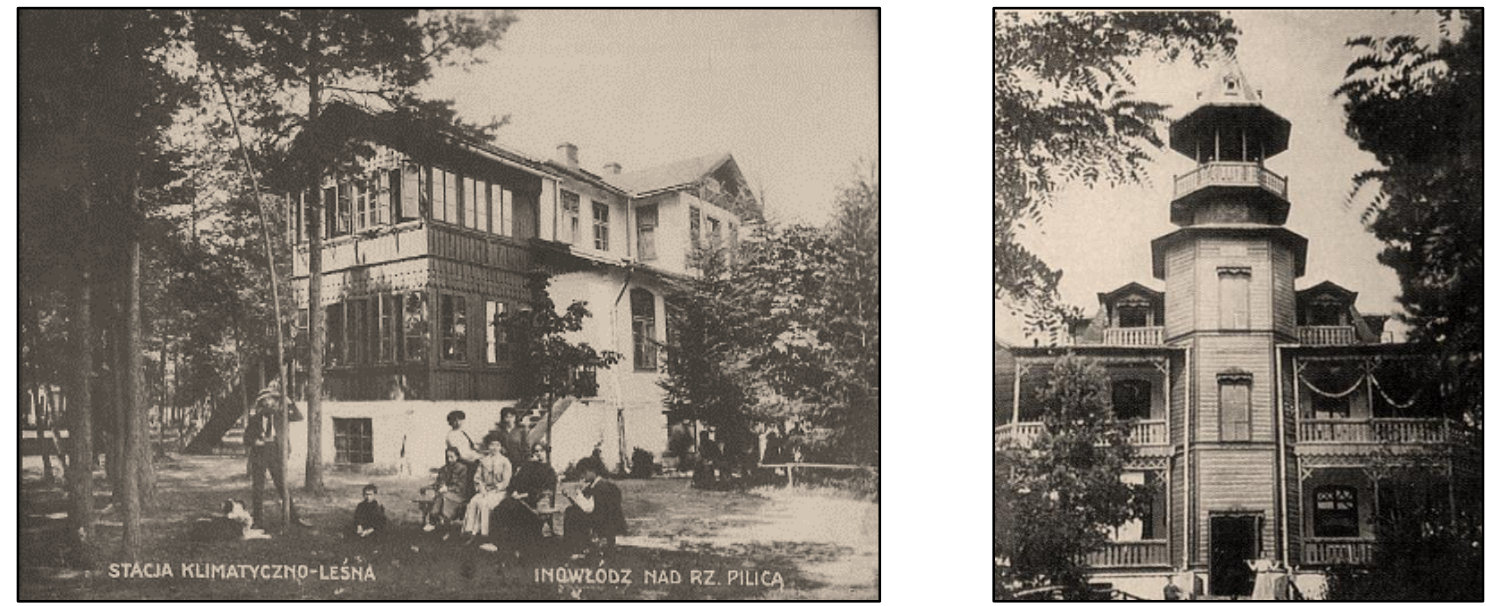

Fot. 2. Stacja klimatyczno-leśna Inowłódz - początek XX w. (Kobalczyk 2017a)

Inowłódz climate and forest station - beginning of the 20th century (Kobalczyk 2017a)

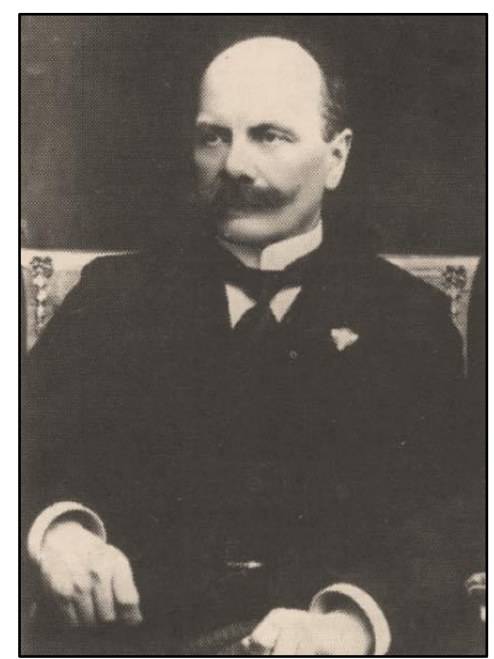

Fot. 3. Michał Rawita-Witanowski (1858-1943) (http://www.dawnypiotrkow.pl)

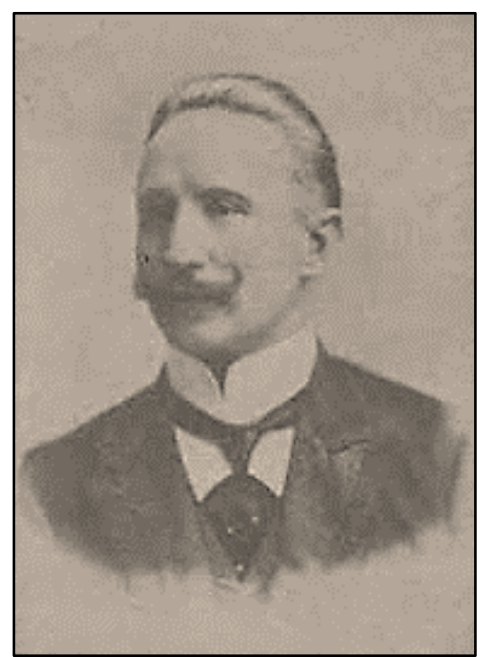

Fot. 4. Jan Czeraszkiewicz (1867-1924) (https://www.ipsb.nina.gov.pl)
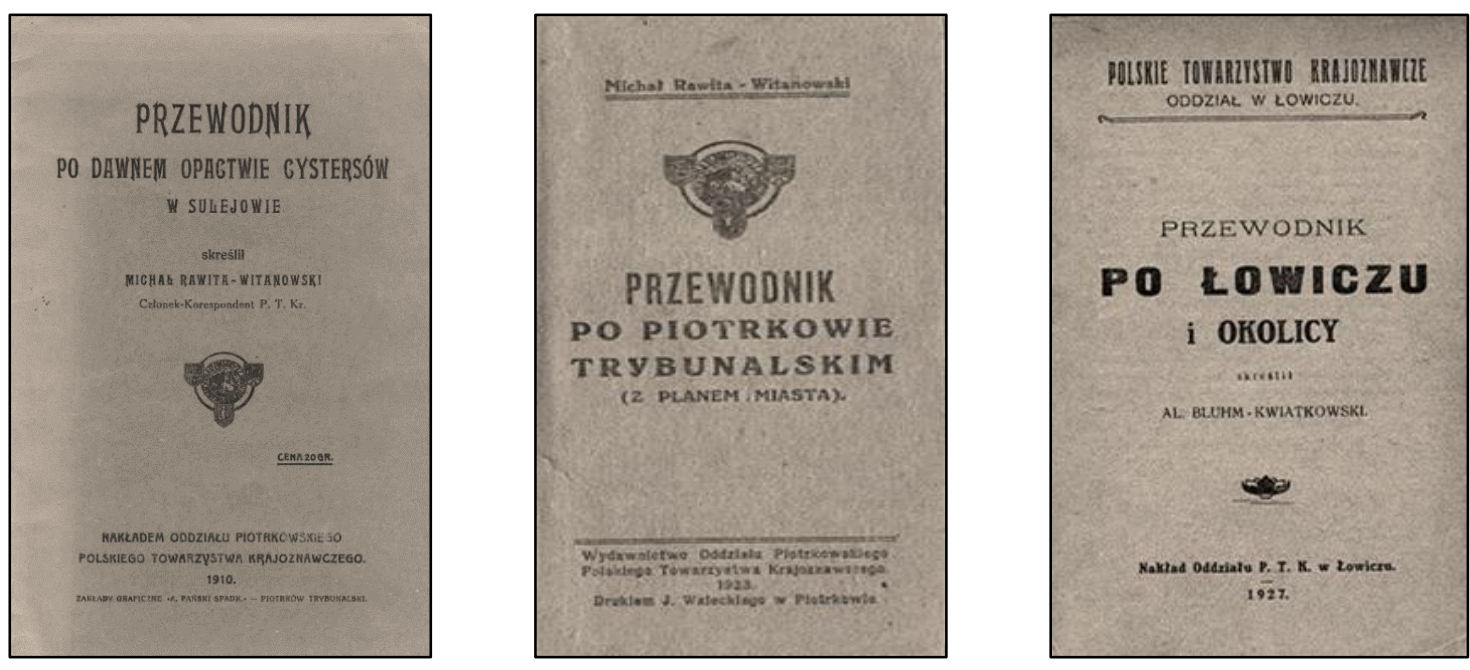

Rys. 2. Okładki pierwszych przewodników turystycznych po regionie łódzkim (http://www.dawnypiotrkow.pl, https://archiwum.allegro.pl)

Covers of the first tourist guides around the Łódź region (http://www.dawnypiotrkow.pl, https://archiwum.allegro.pl) 
Boom budowlany i prosperity łódzkiego przemysłu spowodowały, że był to czas szczytowego rozwoju hotelarstwa łódzkiego. W mieście funkcjonowało wówczas około 30 hoteli. Z tego okresu (początek XX w.) pochodzą m.in. opisany w książce J. Rotha hotel „Savoy” oraz hotel „Polonia Palast”. Obiekty noclegowe ze względu na liczne przyjazdy cudzoziemców (głównie ze wschodu) były nie tylko lokatą kapitału, ale także zyskownym interesem. Podobny poziom, w kontekście liczby obiektów, stolica województwa osiągnęla dopiero $\mathrm{w}$ drugiej dekadzie XXI w. Wybuch I wojny światowej spowodował recesję przejawiającą się m.in. zamykaniem hoteli. Okres Wielkiej Wojny w związku z zahamowaniem aktywności turystycznej nie przyniósł żadnych nowych spektakularnych działań w tym zakresie.

\section{Dwudziestolecie międzywojenne i II wojna światowa}

Okres dwudziestolecia międzywojennego to nie tylko odbudowa i próba integracji podzielonego państwa, ale także rozwój nowych form turystyki (turystyka aktywna i specjalistyczna) oraz zajmowanie nowych obszarów wykorzystywanych później do uprawiania różnych form aktywności turystycznej. W tym okresie rozwijały się zarówno już istniejące, jak i nowe ośrodki turystyczne, m.in. Sulejów, Przygłów, Włodzimierzów. Dużym zainteresowaniem turystów cieszyły się wówczas doliny największych rzek Polski Środkowej - Pilicy i Warty. Carska Spała zamieniła się w rezydencję prezydentów RP, w której organizowane są doroczne dożynki oraz ważne masowe wydarzenia turystyczne, jak np. Jubileu-

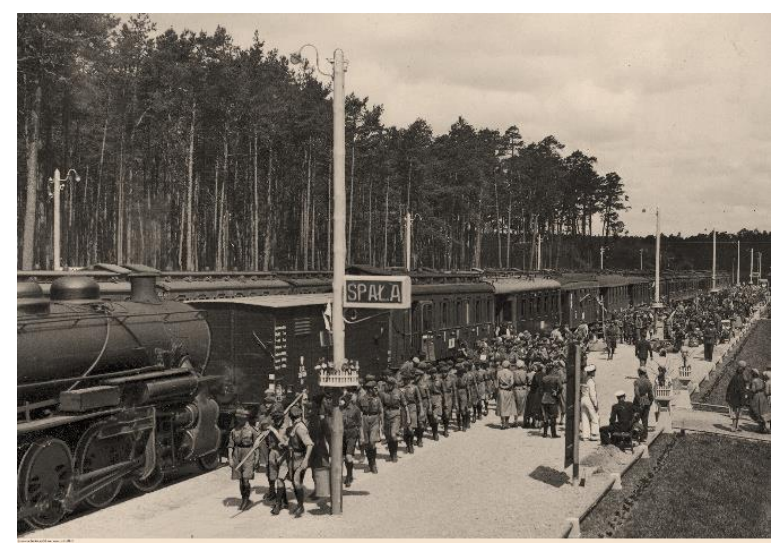

szowy Zlot Harcerstwa Polskiego w 1935 r. (fot. 5). W Piotrkowie Trybunalskim powstaje w 1920 roku Muzeum Krajoznawcze, w 1921 oddział Polskiego Towarzystwa Tatrzańskiego (PTT) w Łodzi, a w 1929 kolejny oddział PTK w Pabianicach.

Bardzo inspirująca okazała się też modna wówczas w Polsce idea E. Howarda - budowy tzw. miast ogrodów, której częściowo zrealizowane założenia możemy obserwować do dziś. Aktywność turystyczna w tym okresie miała charakter w dużej mierze elitarny, a jej formy często ograniczały się w zasadzie do mało aktywnego wypoczynku (wyjazdy na letniska i pobyty zdrowotne). W tym czasie powstał także pierwszy ośrodek wypoczynku zbiorowego w Grotnikach (ośrodek kolonijny - 1924 r.). Okres ten charakteryzował się dalszym wzrostem dostępności komunikacyjnej (kolej kutnowska 1925 r.), możliwością parcelacji gruntów rolnych (reforma rolna - 1925 r.; rys. 3) oraz rozpoczęciem realizacji koncepcji miast ogrodów. Ogłoszono także wykaz miejscowości zaliczanych w regionie do grupy kąpielisk, uzdrowisk i letnisk (rys. 4).

W opisywanym okresie nadal aktywnie funkcjonowały oddziały PTK, organizując m.in. wycieczki do zakładów pracy, wspierając inicjatywę ratowania niszczejącej kolegiaty w Tumie czy zakładając tuż przed drugą wojną światową (1938 r.) Miejskie Schronisko Turystyczne przy ulicy Brzeźnej w Łodzi, w którym organizowano m.in. kursy przewodników po mieście. To także czas założenia (1921 r.) Oddziału Łódzkiego Polskiego Towarzystwa Tatrzańskiego, którego oficjalne zatwierdzenie na Walnym Zjeździe PTT nastąpiło w roku 1923. Działalność oddziału koncentrowała się m.in. na organizacji kursów i wycieczek narciarskich (Historia Oddziału Łódzkiego... 2019).

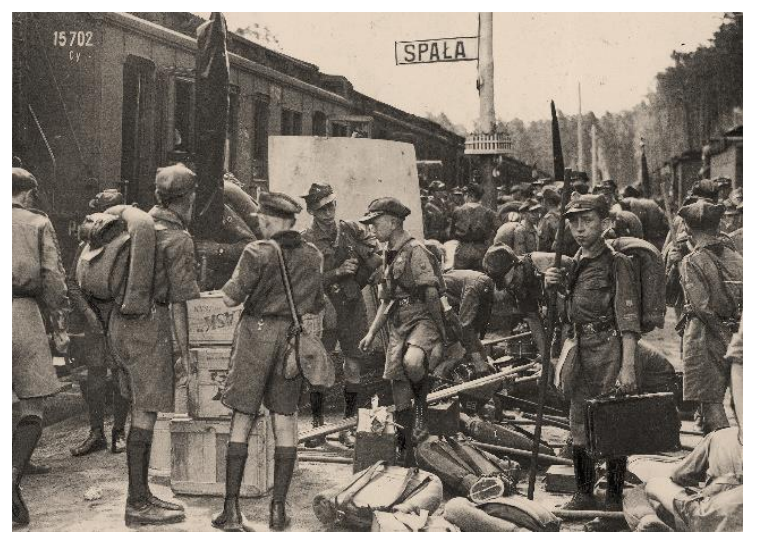

Fot. 5. Jubileuszowy Zlot Harcerstwa Polskiego w Spale (1935) (https://lodzkie.fotopolska.eu) Jubilee Polish Scouting Rally in Spała (1935) (https://lodzkie.fotopolska.eu) 


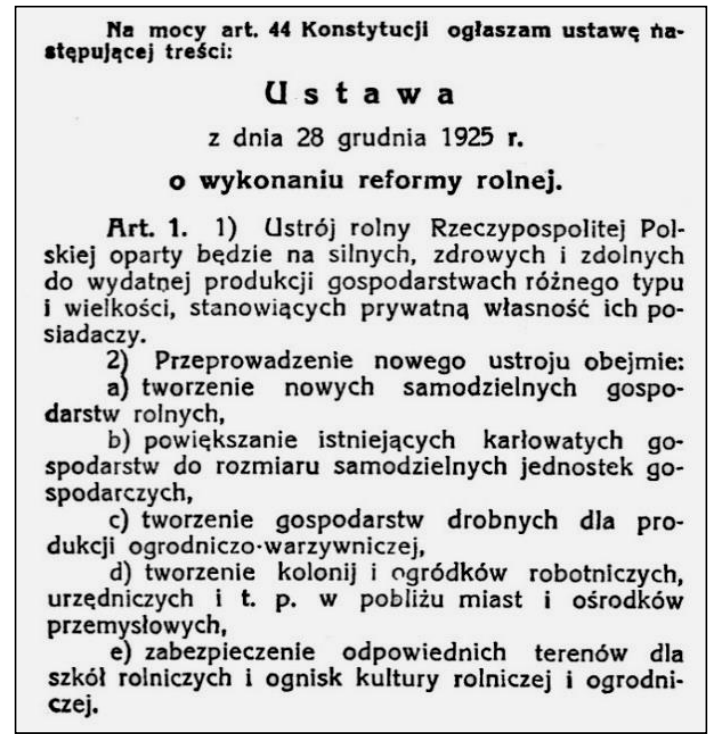

Rys. 3. Fragment Ustawy o wykonaniu reformy rolnej dopuszczającej parcelacje majątków ziemskich w okolicach dużych miast (materiały archiwalne)

Excerpt from the Act on the implementation of land reform permitting parcels of land estates

in the vicinity of large cities (archival materials)

\begin{tabular}{|c|c|c|c|}
\hline \multicolumn{4}{|c|}{234} \\
\hline \multicolumn{4}{|c|}{$\begin{array}{ll} & \text { Załacznik } \\
\text { IZBA SKARBOWA } & \text { ŁoDZKA. }\end{array}$} \\
\hline \multicolumn{4}{|c|}{$\begin{array}{l}\text { W Y K A Z } \\
\text { miejscowości, które zalicza się do kapielisk, uzdro- } \\
\text { wisk i letnisk w okręgu Województwa Lódzkiego. }\end{array}$} \\
\hline L. p. $\quad 1$ & Nazwa & miejscowości. & Powiat. \\
\hline 1. & $\begin{array}{l}\text { Andr } \\
\text { Helen }\end{array}$ & zejów & Łódzki \\
\hline 3. & Ruda & Pabjanicka & $"$ \\
\hline 4. & $W_{\text {isni }}$ & hiowa-Góra & ", \\
\hline 5. & Podd & lebin & " \\
\hline 6. & Będze & & ". \\
\hline 7. & Wykn & & ", \\
\hline 8. & Gatko & ówek & ". \\
\hline 9. & Żakov & wice & " \\
\hline 10. & Warc & chołów & " \\
\hline 11. & Rogó & &. \\
\hline 12. & Bocia. & & 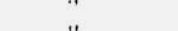 \\
\hline 13. & Kaczl & & ", \\
\hline 14. & Guste & & \\
\hline 15. & Strzel & Inica & Kalïski \\
\hline 16. & Stare & -Miasto & \\
\hline 17. & Mẹck & ra-Wola & Sieradzki \\
\hline 18. & Utrat & & Easki \\
\hline 19. & Roszo & oczyca & Sieradzki \\
\hline
\end{tabular}

Rys. 4. Wykaz miejscowości zaliczanych do kąpielisk, uzdrowisk i letnisk w okręgu województwa łódzkiego (Dziennik Urzędowy Województwa Łódzkiego z 31 maja 1926 r., nr 22, s. 207)

List of localities belonging to bathing areas, spas and holidays in the Lódź region (Official Journal of the Lodz Voivodship of May 31, 1926, No. 22, p. 207)

Tuszyn Las) (rys. 5), wzorowanych na miastach ogrodach E. Howarda. Na tego typu osiedlach wznoszono „drugie domy”, których pierwowzorem - zdaniem Stejskała (1992) - były rezydencje podmiejskie burżuazji łódzkiej. szych miejscowościach, jak i na tzw. surowym korzeniu (takich jak: Sokolniki, Grotniki, Kolumna,
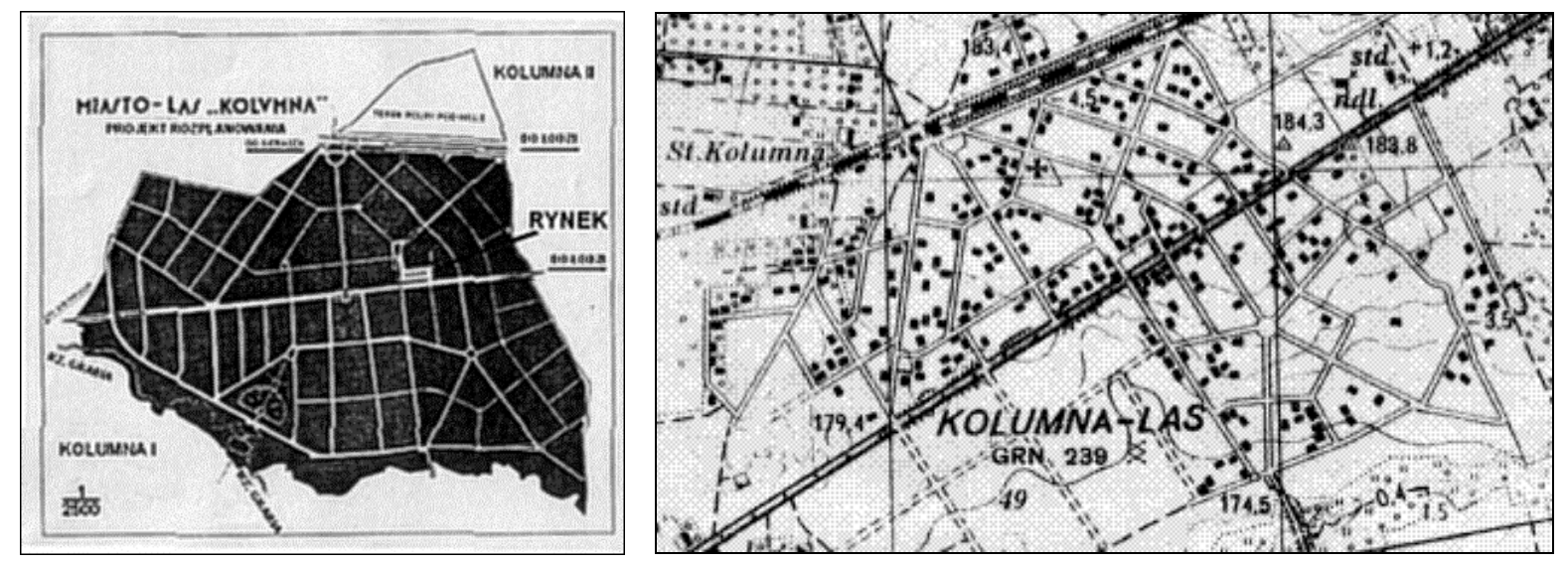

Rys. 5. Planowany (1927) i rzeczywisty (1937) układ przestrzenny miasta lasu Kolumna w okresie dwudziestolecia międzywojennego (Hejneman 2009; stan z 1937 roku opracowano na postawie mapy topograficznej Sztabu Generalnego W.P. w skali 1:50 000)

Planned (1927) and real (1937) spatial layout of the City of Column during the interwar period

(Hejneman 2009, Stan from 1937, developed on the basis of a 1:50,000 topographic map of the General Staff of W.P.) 
Poza granicami miasta na terenach niezbyt oddalonych od miejsca stałego zamieszkania, ale w otoczeniu zieleni, powstawały rezydencje o wysokim standardzie, należące do najbogatszych łodzian, tj. przemysłowców, handlowców, bankierów. Wykupywali oni majątki ziemskie od bankrutującej szlachty, aby w swych nowych reprezentacyjnych posiadłościach wypoczywać, a także przyjmować gości (Stefański 1991).

W tym czasie odbywały się również, głównie latem, wyjazdy osób średniozamożnych na tzw. letniska na otaczające Łódź tereny wiejskie (m.in. do Wiśniowej Góry, Tuszyna, Zofiówki, Rydzynek, Głowna) (rys. 6, 7). Były to przyjazdy jednodniowe lub dłuższe pobyty rodzinne, nawet kilkutygodniowe, $\mathrm{z}$ noclegiem $\mathrm{w}$ wynajmowanych $\mathrm{u}$ rolników mieszkaniach. Opisany proces wynajmowania kwater został uznany przez Liszewskiego (1987) za pierwszą formę ekspansji funkcji wypoczynkowej na tereny podmiejskie.

Pierwsze próby realizacji inwestycji letniskowych i mieszkaniowych w najbliższym sąsiedztwie Łodzi zostały podjęte przez I. Kermenic (wnuczkę J. Heinzla), właścicielkę tzw. Łagiewnik „B” oraz przez władze miasta Łodzi, które wykupily od prywatnych właścicieli część tzw. Łagiewnik „A”. Jednak spory co do sposobu zagospodarowania całego obszaru Lasu Łagiewnickiego (I. Kermenic działki letniskowe, władze miasta - osiedle mieszkaniowe) przedłużały wydanie decyzji przez Okręgowy Urząd Ziemski. W rezultacie realizowane miały być obydwa pomysły.

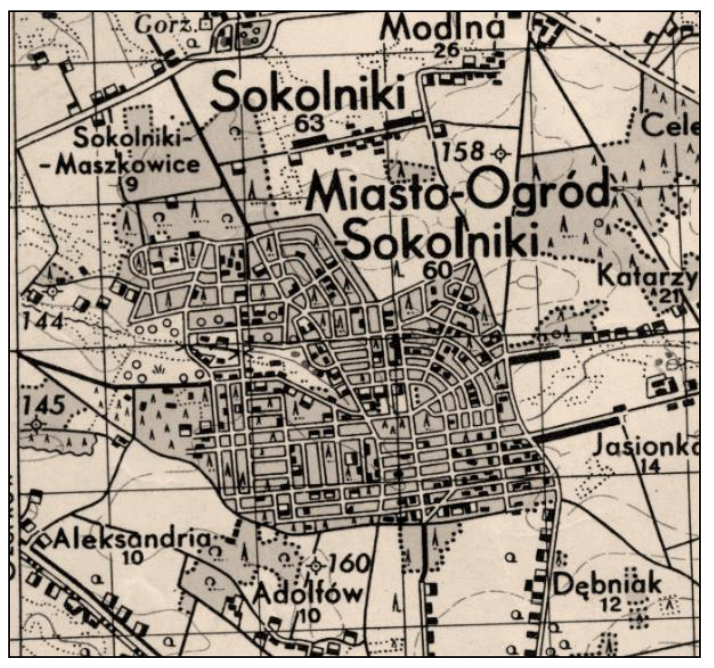

Rys. 6. Stan realizacji miasta ogrodu Sokolniki w 1937 r. (opracowano na postawie mapy topograficznej Sztabu Generalnego W.P. z 1948 r, w skali 1:50 000)

The state of implementation of the Sokolniki City-Garden in 1937 (compiled on the basis of the 1:50,000 topographic map of the General Staff of W.P. from 1948)

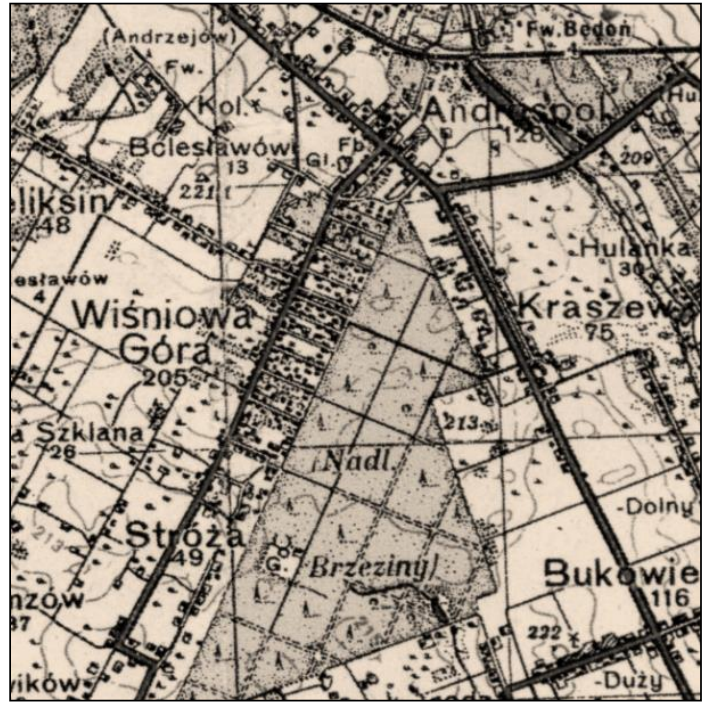

Rys. 7. Rozplanowanie letniska Wiśniowa Góra w 1937 r. w układzie jednoosiowym (wg Matczaka 1984) (Mapa topograficzna WIG z 1937 r., w skali $1: 100000)$

Layout of the Wiśniowa Góra summer resort in 1937 in a single-axis system (according to Matczak 1984) (after the 1:100,000 WIG topographic map from 1937)

$\mathrm{Z}$ powodu istniejącego $\mathrm{w}$ tym czasie poważnego kryzysu gospodarczego, a co za tym idzie trudności finansowych ani wspomniane wcześniej, ani późniejsze próby parcelacji terenów należących do W. Grossmana nie doszły do skutku. Jedyną zrealizowaną inwestycją na terenie Lasu Łagiewnickiego była uroczyście otwarta w $1935 \mathrm{r}$. droga łącząca miasto $\mathrm{z}$ nowym osiedlem mieszkaniowym (obecnie ulica Wycieczkowa). $Z$ całości przedsięwzięcia pozostały jedynie ambitne projekty miasta lasu Łagiewniki, świadczące o dużym rozmachu, funkcjonalności i dbałości o efekty estetyczno-krajobrazowe. Powiodły się natomiast plany utworzenia ,zielonych osiedli” w nieco dalszej odległości od Łodzi. Powstały w tym okresie Grotniki (z parcelacji gruntów należących do Jasieńskich - w 1925 r., i Jungowskich - w 1928 r.), Lućmierz-Las (Rosanów) (na gruntach leśnych należących do Towarzystwa Przemysłowego Leśmierz - po wschodniej stronie linii tramwajowej Łódź-Ozorków) oraz miasto ogród Sokolniki (na gruntach A. Rostockiego - początkowa parcelacja 30 ha gruntu (300 działek) miała miejsce $\mathrm{w}$ na przełomie lat 1928-1929) (Włodarczyk 1999; Makowska-Iskierka 2011; Makowska-Iskierka, Włodarczyk 2012).

Aktywność turystyczna w tym okresie nie ograniczała się jedynie do wyjazdów letniskowych czy zdrowotnych, lecz zaczęła obejmować 
także aktywne formy spędzania wolnego czasu. Znamienne jest pojawienie się pierwszych form wypoczynku zbiorowego (kolonie, obozy letnie). Bardzo istotną cechą tego okresu jest powstanie na tym terenie kilku organizacji wspierających (przynajmniej oficjalnie) rozwój turystyki (m.in. Towarzystwo Obrony Środowiska w Grotnikach - 1928 r. i Stowarzyszenie Właścicieli Nieruchomości miasta ogrodu Sokolniki - 1929 r.).

Lata 1936-1939 przyniosły stałe powiększanie się obszarów kolonizacji turystycznej (parcelacje nowych obszarów leśnych), a także dodatkowe połączenia z Łodzią w sezonie letnim (tzw. zielone linie). Stale i dynamicznie wzrasta ruch turystyczny. Obserwuje się w tym czasie dalszy rozwój zarówno ruchu indywidualnego, jak i grupowego. Ten ostatni obejmuje przede wszystkim wyjazdy kolonijne młodzieży zrzeszonej w YMCA (m.in. Kurnędz i Taraska nad Pilicą) oraz obozy harcerskie. Część zabudowy zmieniła funkcję z obiektów letniskowych (zgodnie z wcześniejszą ideą miast ogrodów) na miejsca stałego zamieszkania. Tym samym zwiększała się liczba stałych mieszkańców tych miejscowości. Pojawiło się także coraz więcej domów letniskowych. Obok tradycyjnych form aktywności turystycznej $\mathrm{w}$ okresie tym zauważalne były wyjazdy niedzielne ludności niezbyt zamożnej, nieposiadającej działek letniskowych (m.in. Wojciechowska 1998).

W czasie drugiej wojny światowej nastąpiło maksymalne ograniczenie aktywności turystycznej społeczeństwa. W tym okresie jedynie Grotniki zachowały charakter miejscowości letniskowej w związku z tym, że duża część działek letniskowych była własnością osób pochodzenia niemieckiego. Wielkość ruchu turystycznego spadła jednak do minimum (w celach turystycznych miejscowość odwiedzali głównie żołnierze i oficerowie niemieccy). Znaczna część zabudowy letniskowej została zniszczona w wyniku działań wojennych, głównie podczas kampanii wrześniowej.

Kryzys hotelarstwa po zakończeniu I wojny światowej spowodował, że działalność hotelarską w Łodzi podjęło tylko siedem obiektów. Dopiero poprawa koniunktury w latach 1926-1929, modernizacja funkcjonującej bazy, budowa nielicznych nowych obiektów (np. „Monopol”) pozwoliły na $\mathrm{w}$ miarę normalne funkcjonowanie bazy noclegowej w stolicy nowo utworzonego województwa. Stan ten nie trwał jednak zbyt długo, kryzys w latach 30. XX w. doprowadził bowiem do zapaści i drastycznego zmniejszenia frekwencji w hotelach i zakładach gastronomicznych.

Podczas II wojny światowej większość hoteli została zajęta przez Niemców i przeznaczona na cele wojskowe. Niemniej jednak pomimo działań wojennych na początku lat 40. Niemcy uruchomili przy ulicy 6 Sierpnia hotel „Cristal”.

\section{Okres państwa socjalistycznego 1945-1989}

Tuż po wojnie, w czasie odbudowy kraju, spektakularnym wydarzeniem było powołanie w Spale w 1949 r. Funduszu Wczasów Pracowniczych. W osadzie w tym czasie dynamicznie rozwijała się funkcja wypoczynkowa. Do początku lat 80. powstało siedem domów wczasowych, m.in.: „Żbik”, „Rogacz”, „Łoś”, „Miś”, „Żubr”, „Dzik”, „Ryś”, z własnym zapleczem rolno-ogrodniczym, dwiema jadalniami (każda na 300 osób), klubokawiarnią, barkiem, wczasowym kinem panoramicznym, sauną, wypożyczalnią rowerów dla dorosłych i młodzieży oraz klubem i świetlicą, salą bilardową i biblioteką. Niektóre $\mathrm{z}$ wymienionych obiektów FWP w Spale funkcjonują do dnia dzisiejszego. Pobliska Konewka stała się rezydencją dygnitarzy PZPR (Liszewski 1991).

Po wojnie, w wyniku tzw. głodu mieszkaniowego, podobnie jak w innych rejonach podłódzkich, ocalałe domy letniskowe zostały przekształcone na mieszkania całoroczne, tracąc przy tym, często nawet w wyglądzie, swój letniskowy charakter. W okresie tym trudno mówić o specyficznych czy nowych formach aktywności turystycznej. Podejmowane działania koncentrowały się głównie na utrzymaniu i remoncie ocalałej bazy.

W samej Łodzi tuż po wojnie nastąpiło przejęcie niektórych hoteli przez Armię Czerwoną na potrzeby wojska, a następnie przekazano funkcjonujące hotele zarządowi miejskiemu, a potem specjalnie utworzonemu przedsiębiorstwu o nazwie „Hotele Miejskie” (od 1974 roku Przedsiębiorstwo Turystyczne „Łódź”). Jedynie hotel „Grand” znalazł się w strukturach organizacyjnych PBT „Orbis" (Milewska, Włodarczyk 2005)

Lata 1950-1959 charakteryzowały się wprowadzaniem nowych przepisów dotyczących parcelacji gruntów oraz wtórną parcelacją działek przedwojennych. Zmiany polityczne doprowadziły do upaństwowienia części majątku i przejęcia przez zakłady pracy przedwojennych ośrodków wypoczynkowych. Osadnictwo letniskowe „wyszło" poza tradycyjne, przedwojenne obszary. W fazie tej występował także stały, aczkolwiek mało dynamiczny wzrost liczby działek i zabudowy letniskowej. W związku z brakiem prowadzenia w początkowym okresie omawianej fazy szczegółowych badań i ewidencji działek dokład- 
niejsze szacunki tego procesu, jak również określenie wielkości ruchu turystycznego nie są możliwe (Włodarczyk 1999).

Rozwój turystyki o charakterze socjalnym, której moderatorem były wówczas najczęściej zakłady pracy, zaowocował powstaniem licznych ośrodków wypoczynkowych, dysponujących dość pokaźnym potencjałem miejsc noclegowych. Przykładem może być Sulejów-Polanka, miejsce koncentracji ośrodków należących do zakładów pracy oraz branżowych związków zawodowych (Wojciechowska 1998). W omawianym okresie powstawały także obiekty należące do różnego rodzaju organizacji społecznych (ZHP, TPD $\mathrm{i}$ in.). Tego rodzaju działalność rozpoczęła się w latach 60. XX w. Miejscowościami, które pod tym względem rozwijały się najbardziej, były podłódzkie Grotniki (Ustronie, Jedlicze), Kolumna, Cyprianów czy Cesarka koło Strykowa. W tym samym czasie oprócz wypoczynku na działkach letniskowych oraz wczasach i koloniach coraz większą popularność zdobywały krótkoterminowe formy aktywności turystycznej, takie jak: rajdy, wycieczki, majówki, organizowane głównie przez instytucje społeczne i zakłady pracy. Tworzona wtedy baza o przeciętnym standardzie posiadała relatywnie słabe wyposażenie rekreacyjne, pomimo że budowane ośrodki miały większą powierzchnię użytkową oraz znajdowały się na znacznie większych działkach od tych z okresu przedwojennego (fot. 6, 7). Sukcesywnie postępowało zagospodarowywanie obszarów penetracji turystycznej poprzez tworzenie pieszych znakowanych szlaków turystycznych, w tym głównego szlaku turystycznego okolic Łodzi (oznakowanego kolorem czerwonym).

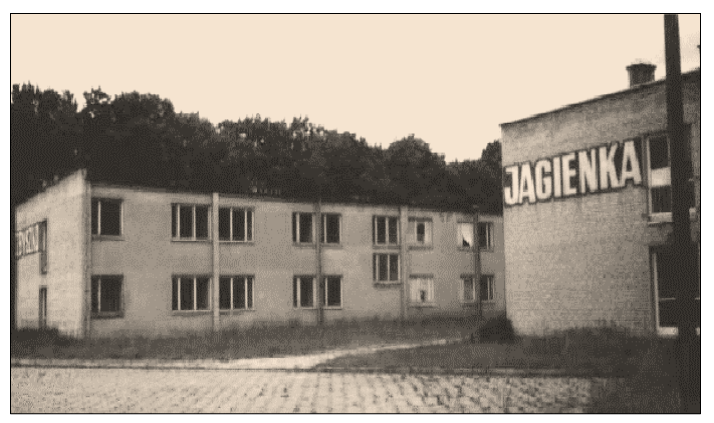

Fot. 6. Ośrodek Szkoleniowo-Konferencyjny

„Zamek” w Uniejowie - pawilony „Zbyszko” i „Jagienka”stan z roku 2004 r. (Milewska, Włodarczyk 2005)

\section{Conference Centre}

"Zamek" in Uniejów - "Zbyszko" and "Jagienka" pavillions - state in 2004 (Milewska, Włodarczyk 2005)

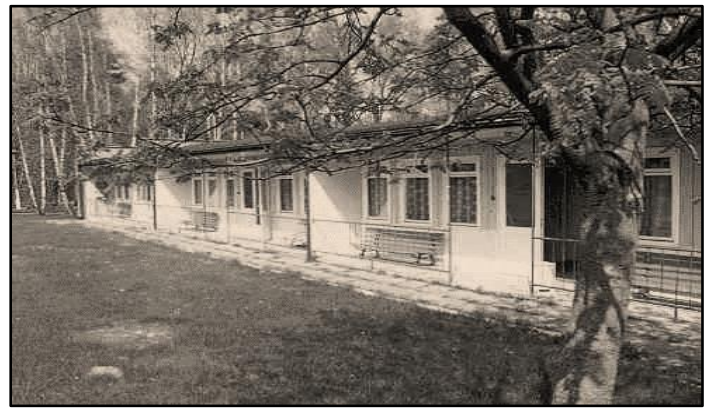

Fot. 7. Typowa architektura ośrodków wypoczynkowych z lat 70. i 80. XX w. - ośrodek „Boruta” w Grotnikach (Milewska, Włodarczyk 2005)

A typical architecture of holiday resorts from the 1970s and 80s - the "Boruta" resort in Grotniki

(Milewska, Włodarczyk 2005)

Sytuacja obszaru nieco się zmieniła w momencie wybudowania jednego $\mathrm{z}$ największych sztucznych zbiorników wodnych Polski Środkowej, jakim jest Zalew Sulejowski. Plany były bardzo ambitne, ale późniejsza realizacja bardzo rozminęła się z założeniami. Od 1973 r. ośrodki wypoczynkowe powstające nad nowo wybudowanym Zbiornikiem Sulejowskim miały być lokalizowane w przewidzianych w ogólnym zagospodarowaniu przestrzennym jeziora tzw. JOR-ach, czyli Jednostkach Osiedleńczo-Rekreacyjnych, oraz SOR-ach, tj. Samodzielnych Ośrodkach Rekreacyjnych. W planie tym przewidziano wówczas powstanie siedmiu JOR-ów, noszących nazwy: Kuba (Huby), Borki, Tresta, Karolinów, Obdzież, Dobra Woda, Polanka-Przygłów, a także trzech SOR-ów: dwóch w Zarzęcinie i jednego w Barkowicach Mokrych (rys. 8). $\mathrm{Z}$ tego olbrzymiego, jak na owe czasy, założenia stworzono (i to tylko w niewielkiej części) dwa JOR-y, tj. Polanka-Przygłów oraz Borki (Wojciechowska 1998).

Gigantyczny projekt zagospodarowania obrzeży zbiornika wyłoniony w wyniku ogólnopolskiego konkursu przewidywał powstanie nad Zalewem siedmiu miasteczek turystycznych. Miała to być zabudowa gniazdowa, a więc pozostawiająca $\mathrm{w}$ stanie nienaruszonym i naturalnym tereny zielone rozdzielające poszczególne JOR-y. Ich ochronę miała dodatkowo zapewnić obwodnica z siecią parkingów oraz opaskowym kolektorem sanitarnym. Wybudowany w 1986 r. zbiornik Jeziorsko nie doczekał się tak ambitnych planów zagospodarowania i jest mniej intensywnie wykorzystywany turystycznie, ale stał się ważną atrakcją turystyczną regionu (rezerwat ornitologiczny, zawody motorowodne). 


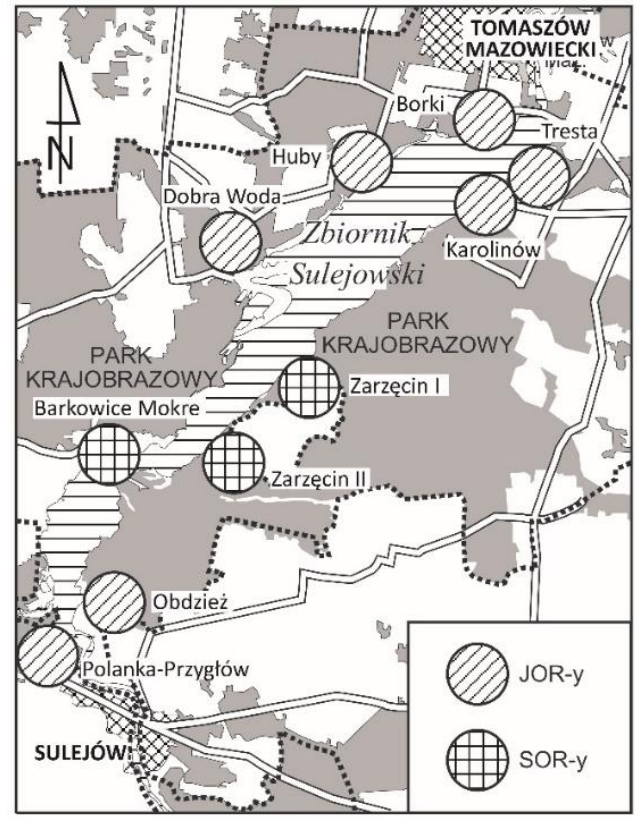

Rys. 8. Planowane rozmieszczenie JOR-ów (Jednostek Osiedleńczo-Rekreacyjnych) i SOR-ów

(Samodzielnych Ośrodków Rekreacyjnych) nad Zbiornikiem Sulejowskim w połowie lat 70. XX w.

The planned deployment of JORs (Settlement and Recreation Centres) and SORs (Independent Recreation Centres) over the Sulejowski Reservoir in the mid-1970s

W latach 1978-1988 na terenie regionu powołano cztery parki krajobrazowe (Załęczański PK - 1978 r., Bolimowski PK - 1986 r., PK Warty i Widawki - 1987 r., Przedborski PK 1988 r.), w których oprócz działalności o charakterze ochronnym przygotowywano infrastrukturę oraz promowano rozwój odpowiedzialnej turystyki na administrowanych przez nie obszarach.

Połowa lat 70. to także pierwsze próby adaptowania do celów noclegowych obiektów zabytkowych. Jednym z pierwszych był zamek biskupi $\mathrm{w}$ Uniejowie. Wraz $\mathrm{z}$ dwoma pawilonami „Zbyszko” i „Jagienka” (fot. 6) stanowił on od drugiej połowy lat 70. ośrodek wypoczynkowy WOSiR i był użytkowany głównie przez studentów (Wiluś 1997). Po kompleksowym remoncie w latach 90. został przekształcony w hotel, a po wprowadzeniu po 1997 r. nowych zasad kategoryzacji funkcjonuje do chwili obecnej jako ośrodek szkoleniowo-konferencyjny. W latach 19952009 jego gospodarzem była Rada Naczelna Zrzeszenia Studentów Polskich. Obecnie zamek należy do Przedsiębiorstwa Gospodarki Komunalnej Termy Uniejów Sp. z o.o. W 2012 r. budynek został gruntownie odrestaurowany. Obecnie jest to stylowy obiekt hotelowy wraz z centrum konferencyjnym oraz restauracją.

Lata 70. XX w. to także początki kształcenia na poziomie wyższym specjalistów z zakresu turystyki. Prekursorem w tym względzie był Uniwersytet Łódzki, w którym w 1977 r. uruchomiono Podyplomowe Studium Turystyki, a następnie (w 1982 r.) - specjalizację w ramach kierunku geograficznego (rys. 9).

Charakteryzowany okres odznaczał się także dynamiczną działalnością Polskiego Towarzystwa Turystyczno-Krajoznawczego (1951 r.), które oprócz propagowania poprzez imprezy masowe turystyki dla wszystkich (m.in. rajdy piesze) realizowało inne formy upowszechniania aktywności

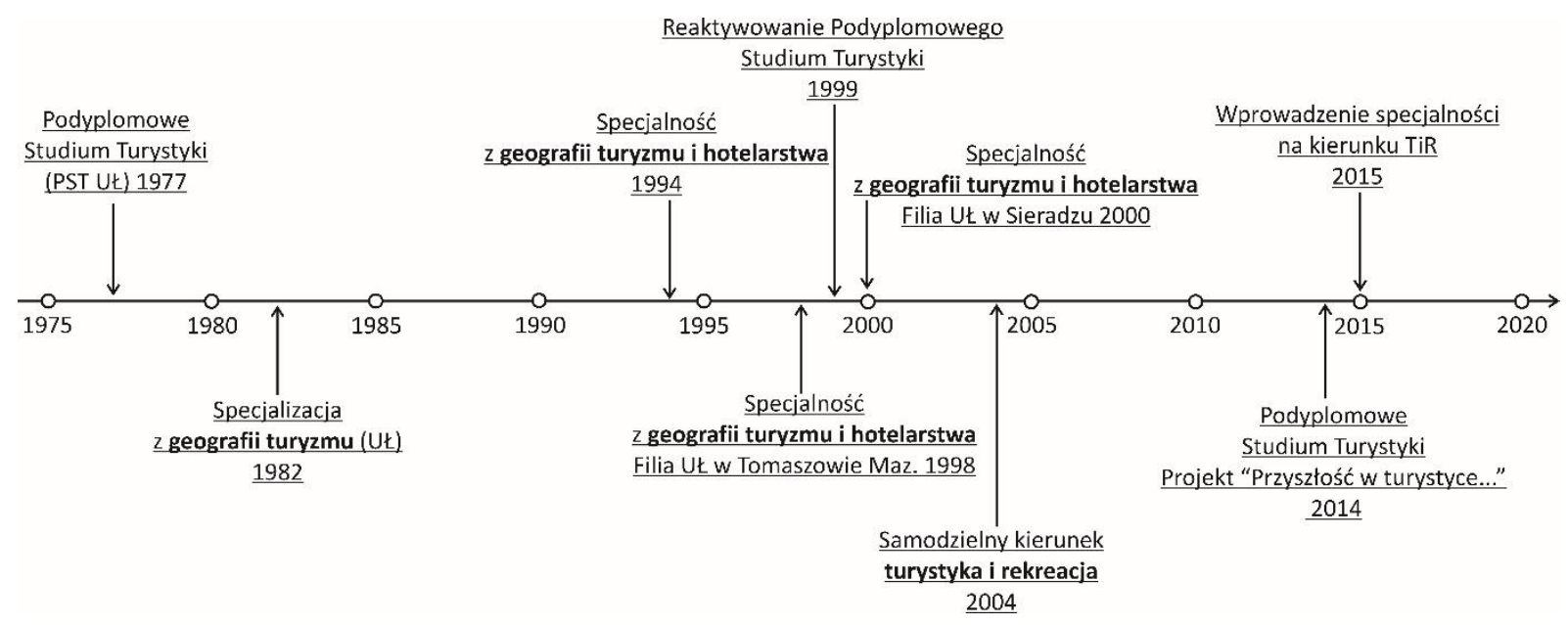

Rys. 9. Historia kształcenia kadr dla potrzeb turystyki na Uniwersytecie Łódzkim

History of staff education for the needs of tourism at the University of Lodz 
i wiedzy turystycznej. Powstawały wówczas zakładowe koła PTTK oraz sekcje turystyki kwalifikowanej (specjalistycznej). W tym okresie w strukturach Oddziału Łódzkiego PTTK im. Jana Czeraszkiewicza utworzono m.in. Koło Przewodników Turystycznych (1952 r.; od 2013 r. roku patronem koła jest im. Rajmund Rembieliński), Koło Terenowe Kolarzy (1956 r.; obecnie Łódzki Klub Turystów Kolarzy), Klub Turystów Górskich „Kosówka” (1958 r.), Jacht Klub (1958 r.), Klub Płetwonurków „Tryton” (1959 r.; pierwotna nazwa: Łódzki Klub Turystyki Podwodnej), Klub Narciarski (1959 r.), Łódzki Klub Kajakowy „Albatros” (1961 r.), Klub Turystów Pieszych "Salamandra” (1962 r.), Łódzki Klub Alpejski „Szarotka” (1984 r.) oraz Łódzki Klub Campingu i Caravaningu (1986 r.). W 2019 r. oddział będący spadkobiercą łódzkiego PTT obchodził jubileusz 110-lecia istnienia (Historia Oddziału Łódzkiego... 2019).

Wśród podjętych inicjatyw należy wymienić także m.in. wydawnictwo „Wędrownik” (od 1956 r. - Regionalna Pracownia Krajoznawcza w Łodzi; rys. 10), organizację Muzeum Miasta i Rzeki Warty (przy oddziale PTTK w Warcie), periodyk „Na sieradzkich szlakach” (od 1985 r. - oddział PTTK w Sieradzu, rys. 11) czy powołanie w 1988 r. Centrum Fotografii Krajoznawczej w Lodzi (Śledzińska 2009).

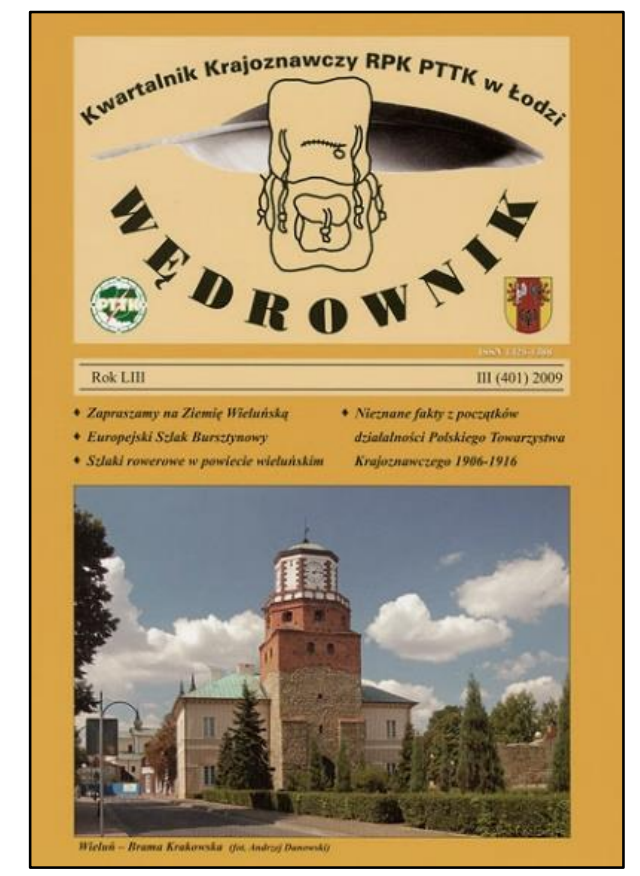

Rys. 10. Okładka czasopisma „Wędrownik” (zbiory autora)

Wędrownik magazine cover (author's archive)

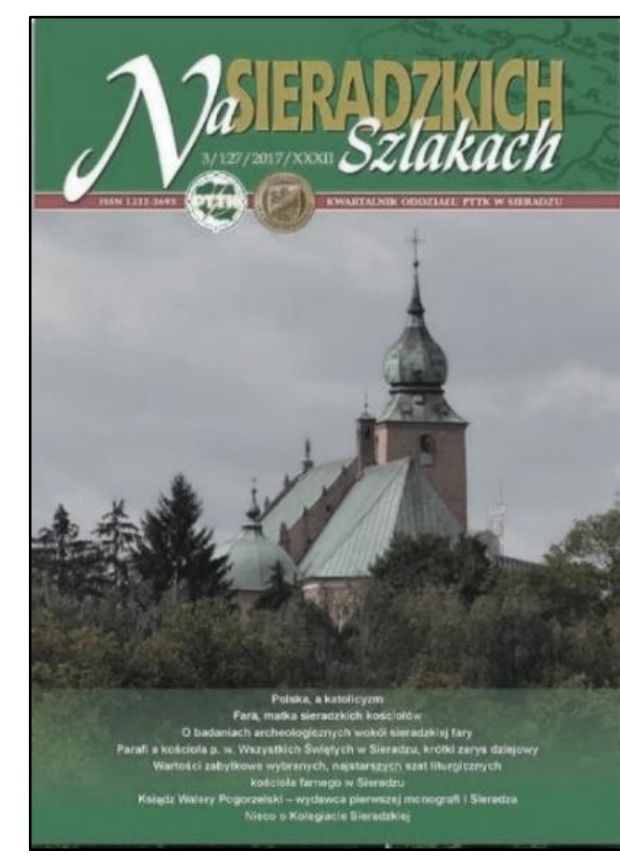

Rys. 11. Okładka czasopisma „Na Sieradzkich Szlakach" (zbiory autora)

Na sieradzkich szlakach magazine cover (author's archive)

Wśród działań podejmowanych w zakresie aktywności turystycznej zaznaczył się dynamiczny rozwój osadnictwa letniskowego poza wytworzonymi wcześniej jądrami kolonizacyjnymi. Nową formą zagospodarowania przestrzeni turystycznej stały się kompleksy pracowniczych ogródków działkowych pojawiające się głównie w okolicach większych miast (m.in. Szkup 2003). Wprowadzenie wolnych sobót znacznie przyczyniło się do wzrostu wyjazdów weekendowych, które koncentrowały się w nowo zagospodarowywanych ośrodkach w Malince, Głownie, Cesarce czy Dzierżąznej. Nowe formy zagospodarowania turystycznego sprawiły, że niektóre incydentalne formy rekreacji zaczęly być coraz popularniejsze (np. rekreacja przywodna - kajaki, rowery wodne itp.), a także pojawily się nowe, nieobserwowane dotychczas na tym obszarze (np. narciarstwo w Malince i Smardzewie). Nie słabło zainteresowanie wędrówkami krajoznawczymi, o czym świadczą wyznaczone w tym okresie nowe odcinki pieszych szlaków turystycznych (Włodarczyk 1999).

\section{Okres po 1989 roku}

Przemiany polityczno-społeczne oraz gospodarcze, które nastąpiły po 1989 r., w wyraźny sposób wpłynęły zarówno na podejmowane formy aktywności turystycznej, jak i instytucjonalny charak- 
ter turystyki jako zjawiska. Dlatego najnowsze dzieje turystyki w regionie łódzkim można podzielić jeszcze na dwa podokresy wyraźnie różniące się od siebie.

\section{Faza do przełomu wieków}

Pierwsze lata nowej rzeczywistości polityczno-gospodarczej zaowocowały żywiołowym rozwojem niektórych aspektów działalności i aktywności turystycznej. Zaliczyć do nich można powstawanie nowych prywatnych obiektów noclegowych i gastronomicznych, swoistą restytucję gospodarstw agroturystycznych, dzierżawę dawnych zakładowych ośrodków wypoczynkowych, a także prywatyzację oraz indywidualizację działań związanych z turystyką.

Zaspokojenie w znacznym stopniu popytu na miejsca noclegowe w obiektach wypoczynkowych, zmiany ustrojowe otwierające szeroki możliwości podróżowania, już nie tylko po obszarze regionu czy kraju, a także wzrastająca konkurencja de facto stały się przyczyną zmian zachodzących w tym okresie. Przekształcenia te były związane przede wszystkim z zarządzaniem oraz użytkowaniem obiektów kolonijnych i zakładowych ośrodków wypoczynkowych. W końcowym okresie tej fazy w większości obiektów zastosowano różnego rodzaju formy ajencji i dzierżaw. W części ośrodków w wyniku rozpoczętych procesów prywatyzacji zmienił się także właściciel. Pojawiająca się na rynku turystycznym konkurencja, upadek niektórych przedsiębiorstw, wzrost wymagań klientów oraz rosnące koszty utrzymania przestarzałej często bazy spowodowały likwidację części ośrodków. Właściwie nie powstawały wówczas nowe obiekty o charakterze wczasowo-kolonijnym. Zasady gospodarki rynkowej, a co za tym idzie wzrost aktywności konkurencji wymusiły podjęcie działań promocyjnych oraz zastosowanie nowych metod pozyskiwania klientów. Proponowana oferta przygotowywana była dużo staranniej, praktycznie w całości stając się ogólnodostępną.

Pojawiły się materiały reklamowe (ulotki, broszury) i ogłoszenia w prasie lokalnej i regionalnej, podwyższył się standard oferowanych usług (szczególnie w drugiej części opisywanej fazy). Oferty wypoczynku na obszarze krawędzi Wyżyny Łódzkiej znalazły się w części (niewielkiej) żywiołowo rozwijających się w tym okresie łódzkich biur podróży (m.in. biuro turystyczne W. Marzyńskiego czy późniejsza regionalna Agencja Turystyczna „Grand Tour”) (Bonisławski 1995). W ostatnich latach tej fazy oferty z obszaru północnej części krawędzi Wyżyny Łódzkiej pojawiły się na regionalnych targach turystycznych „Na styku kultur", które w 2019 r. obchodziły jubileusz 25-lecia funkcjonowania (rys. 12). Zaczęły powstawać także instytucje samorządu branżowego, wśród których należy wymienić Polską Izbę Turystyki, Izbę Turystyki Ziemi Łódzkiej czy Polska Izbę Turystyki Młodzieżowej.

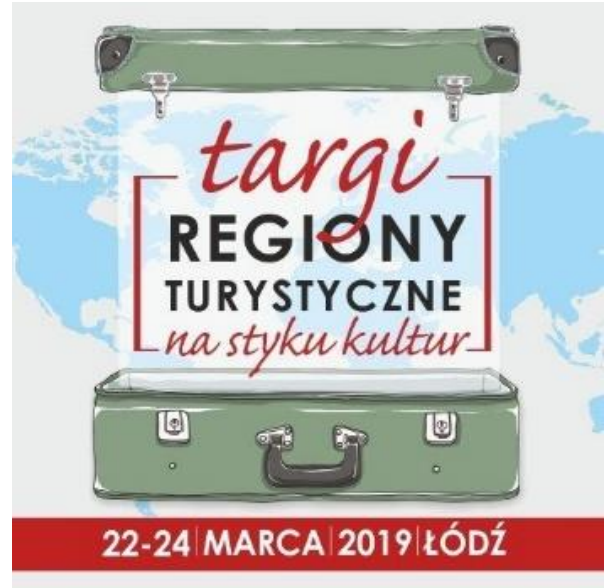

Rys. 12. Targi turystyczne - plakat (zbiory autora)

Tourism fair poster (author's archive)

Oprócz działań zmierzających do zwiększenia zainteresowania obszarem zaznaczyły się także tendencje negatywnie wpływające na wielkość ruchu turystycznego. Było to przede wszystkim ograniczenie opieki socjalnej ze strony zakładów pracy oraz stale zmniejszająca się rola komunikacji kolejowej (likwidacja części połączeń podmiejskich i kas biletowych), powodująca ograniczenie dostępności części obszaru dla osób nie posiadających własnego środka lokomocji.

Nastąpiło także znaczne spowolnienie dynamiki przyrostu wielkości obszarów kolonizowanych przez osadnictwo turystyczne, coraz mniej budowano domów letniskowych. Rozpoczęte w latach dziewięćdziesiątych działania Wojewódzkiego Ośrodka Doradztwa Rolniczego mające na celu stworzenie sieci gospodarstw agroturystycznych zakończyły się w zasadzie niepowodzeniem. Przyczyną takiego stanu rzeczy nie było małe zainteresowanie łodzian tą formą aktywności turystycznej, ale brak odpowiedniej bazy na wsiach oraz fakt, że do większości gospodarstw na badanym terenie w okresie wakacyjnym przyjeżdżała rodzina z miasta. Tak więc tradycyjne letniska zostały zastąpione podobnymi wyjazdami, ale o innym charakterze. W takim układzie masowy powrót do mających na tym obszarze jeszcze przedwojenne tradycje wyjazdów „na letnisko” jest na razie mało prawdopodobny. Nie oznacza to, że w granicach woje- 
wództwa nie ma gospodarstw agroturystycznych. Statystyki Urzędu Marszałkowskiego Województwa Łódzkiego, będącego organizatorem konkursu „Złota Grusza”, potwierdzają stały rozwój tego rodzaju obiektów turystycznych, koncentrujących się na terenach dolin rzek Grabi, Pilicy oraz na północnej krawędzi Wyżyny Łódzkiej (Wojciechowska 2018).

Wszystkie przedstawione przemiany zachodzące w tej fazie doprowadziły nie tyle do drastycznego zmniejszenia się wielkości ruchu turystycznego, ile do zmiany proporcji w jego strukturze. Bardzo wyraźnie zmniejszyła się wielkość zorganizowanych form tego ruchu na korzyść aktywności indywidualnej.

Bardzo istotny wpływ na rozwój aktywności turystycznej obszaru miało ustanowienie kolejnych parków krajobrazowych (Sulejowski PK - 1994 r., Spalski PK - 1995 r., PK Wzniesień Łódzkich 1996 r.). Paradoksalnie wzrost turystycznego zainteresowania obszarami parków wiąże się z ograniczeniami w ich użytkowaniu. Na terenie parków istnieją obszary penetracji, asymilacji, jak i kolonizacji turystycznej. W czasie kilkudziesięcioletniego funkcjonowania w Polsce Środkowej parków krajobrazowych na ich terenie wyznaczono nowe szlaki piesze i rowerowe, a znajomość terenu wśród rzeczywistych i potencjalnych turystów zdecydowanie poprawiła się poprzez zakrojoną na szeroką skalę działalność edukacyjną prowadzoną przez dyrekcję i pracowników powołanego w 2013 r. Zespołu Parków Krajobrazowych Województwa Łódzkiego.

Rozwój miejskiej bazy noclegowej w tej fazie polegał głównie na budowie nowych, niewielkich hoteli prywatnych (m.in. Alicja, Yuca) oraz przekształcaniu dawnych hoteli robotniczych w obiekty ogólnodostępne (np. hotel Boss). Różnicowały się także struktura rodzajowa i standard funkcjonujących obiektów. Baza środowiskowa przekształcała się w ogólnodostępną.

\section{Faza po 2000 r.}

Cechą tego okresu jest uspokojenie żywiołowego rozwoju charakterystycznego dla młodej gospodarki rynkowej fazy poprzedniej. Dotychczasowy szybki wzrost ilościowy infrastruktury uzupełniany jest działaniami projakościowymi mającymi na celu poprawę standardu obiektów i świadczonych usług. Pojawiają się wysokiej klasy czterogwiazdkowe hotele (np. „Mościcki” w Spale, „Ossa” w Ossie), na rynek hotelarski największych miast $\mathrm{w}$ regionie weszły zagraniczne systemy i łańcuchy hotelowe (m.in. „Accor”, „Hilton”, „Holiday Inn”, „Campanile”,
„Andel's"), rozwija się hotelarstwo rodzime (np. sieć łódzkich hoteli „Ambasador”). Zmienia się także lokalizacja nowych obiektów noclegowych, powstają obiekty niespotykane wcześniej w regionie (np. hostele). Zakrojone na niespotykaną dotąd skalę działania rewitalizacyjne i modernizacyjne doprowadzily do powstania nowych przestrzeni publicznych, będących jednocześnie sztandarowymi atrakcjami turystycznymi nie tylko Łodzi, ale także całego regionu (np. Manufaktura, EC-1). Utworzone na bazie dawnego gospodarstwa rolnego pole golfowe w Woli Błędowej stanowi alternatywę dla osób poszukujących ekskluzywnych rozrywek.

Do największych inwestycji turystycznych zrealizowanych w tej fazie trzeba zaliczyć zagospodarowanie turystyczne Góry Kamieńsk (zwałowisko zewnętrzne KWB Bełchatów), budowę wielofunkcyjnej hali widowiskowej Atlas Arena oraz Areny Lodowej w Tomaszowie Mazowieckim. Ewenementem na skalę kraju jest rozwój pierwszego w Polsce uzdrowiska termalnego i kompleksu termalno-basenowego w Uniejowie.

Jak nigdy wcześniej w regionie i jego stolicy organizowane są wydarzenia kulturalne, sportowe i turystyczne, stające się powoli marką-wyróżnikiem Łódzkiego. Należały i należą do nich m.in.: Festiwal „Kolory Polski”, Camerimage, Transatlantyk, Light Move Festival (ponad 700 tys. odwiedzających w 2018 r.). Stolica województwa jest także organizatorem licznych imprez sportowych o zasięgu krajowym i międzynarodowym. W wielofunkcyjnej hali widowiskowej Atlas Arena odbyły się m.in. Mistrzostwa Świata w Piłce Siatkowej Mężczyzn (2014 r.), a wiosną 2019 r. miasto było gospodarzem Mistrzostw Świata w Piłce Nożnej U-20.

Krokiem milowym instytucjonalnego rozwoju turystyki w regionie było powstanie w 2003 r. Regionalnej Organizacji Turystycznej Województwa Łódzkiego, skupiającej w swoich szeregach podmioty gospodarcze, jednostki samorządu terytorialnego, lokalne organizacje turystyczne, organizacje społeczne, instytucje kultury, szkoły średnie i wyższe związane z turystyką. ROT WŁ prowadzi zakrojoną na szeroką skalę działalność organizacyjną, informacyjną, wydawniczą (rys. 13, 14, 15) i jest ważnym reprezentantem dużej części środowiska turystycznego regionu. W 2011 r. województwo łódzkie jako trzecie w Polsce wzbogaciło się o kanon krajoznawczy wydany przez PTTK przy finansowej współpracy Urzędu Marszałkowskiego Województwa Łódzkiego (rys. 14). 


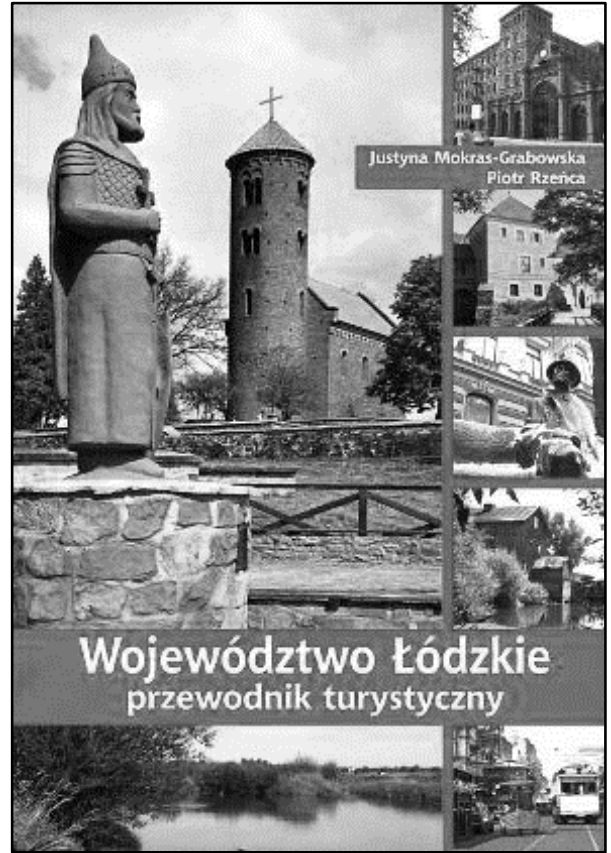

Rys. 13. Przewodnik po województwie łódzkim autorstwa J. Mokras-Grabowskiej i P. Rzeńcy (archiwum autora)

Guide to the Łódź region by J. Mokras-Grabowska and P. Rzeńca (author's archive)

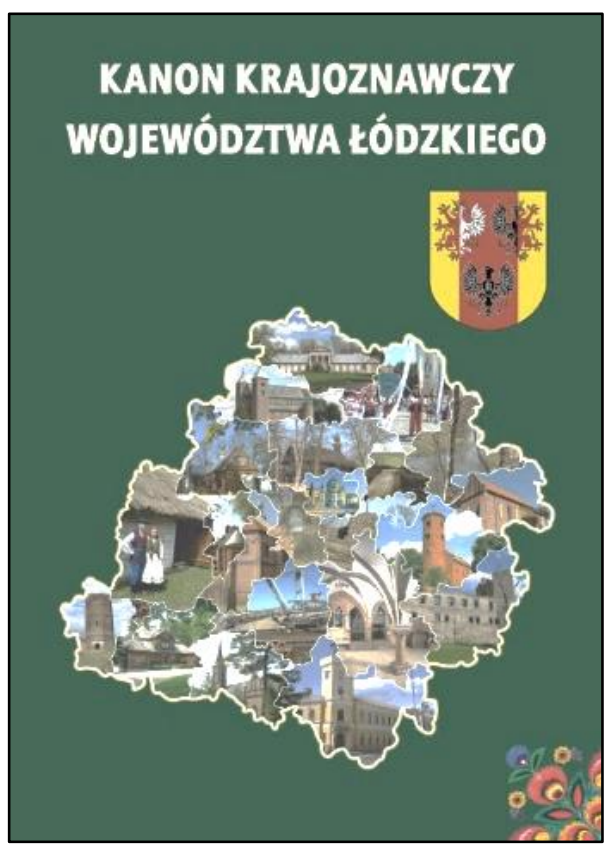

Rys. 14. Kanon krajoznawczy województwa tódzkiego pod redakcją J. Śledzińskiej, A. Wielochy i B. Włodarczyka (archiwum autora)

The sightseeing canon of the Lodz region, ed. J. Śledzińska, A. Wielocha, B. Włodarczyk (author's archive)

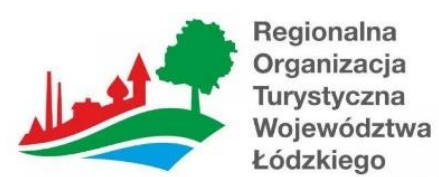

Rys. 15. Logo ROT WŁ (www.rowl.pl)

ROT WŁ logo (www.rowl.pl)

Efektem współpracy ROT WŁ, UM WŁ oraz pracowników Instytutu Geografii Miast i Turyzmu był kilkuletni monitoring ruchu turystycznego, prowadzonym w latach 2009-2012 (rys. 16). W omawianej fazie powstają i są publikowane także ważne dokumenty dotyczące rozwoju turystyki o charakterze strategicznym dla regonu i jego stolicy (rys. 17).

Wejście Polski do Unii Europejskiej w 2004 r. zaowocowało pozyskaniem środków finansowych także na inwestycje turystyczne. Najbardziej spektakularną wydaje się liczący prawie 2000 km Łódzki Szlak Konny i związany z nim program „Końska Dawka Przygody”.

Kolejnym aspektem, szczególnie ważnym z punktu widzenia nowych inwestycji (niestety nieturystycznych), są ,korytarze” stworzone przez oddane do użytku autostrady A-1 i A-2 oraz drogi szybkiego ruchu S-8 i S-14. Ceny działek szczególnie w okolicach węzłów wzrosły kilkunastokrotnie. Uruchomienie węzła autostrad A-1/A-2, rozcinającego Park Krajobrazowy Wzniesień Łódzkich, pozwala przypuszczać, że zmieni się także struktura bazy noclegowej badanego terenu. Prawdopodobnie uruchomienie odcinków obu autostrad dzielących obszar województwa na cztery części będzie bardzo poważną determinantą jego dalszego rozwoju turystycznego. Pomimo olbrzymiego zwiększenia dostępności obszaru (co teoretycznie powinno stymulować rozwój) pojawiające się centra logistyczne, magazyny i węzły komunikacyjne powodują dysonans $\mathrm{w}$ krajobrazie, co z kolei obniża nie tylko jego atrakcyjność, ale także całej przestrzeni turystycznej. Paradoksalnie tak dobra infrastruktura drogowa może spowodować, że obszar województwa stanie się niestety jedynie regionem tranzytowym na trasach północpołudnie i wschód-zachód.

\section{Podsumowanie}

W rozwoju turystyki regionu łódzkiego, rozumianym zarówno jako podejmowanie aktywności turystycznej, jak i powstawanie struktur organizacyjnych $\mathrm{w}$ wymiarze instytucjonalnym, można wyróżnić kilka charakterystycznych okresów 

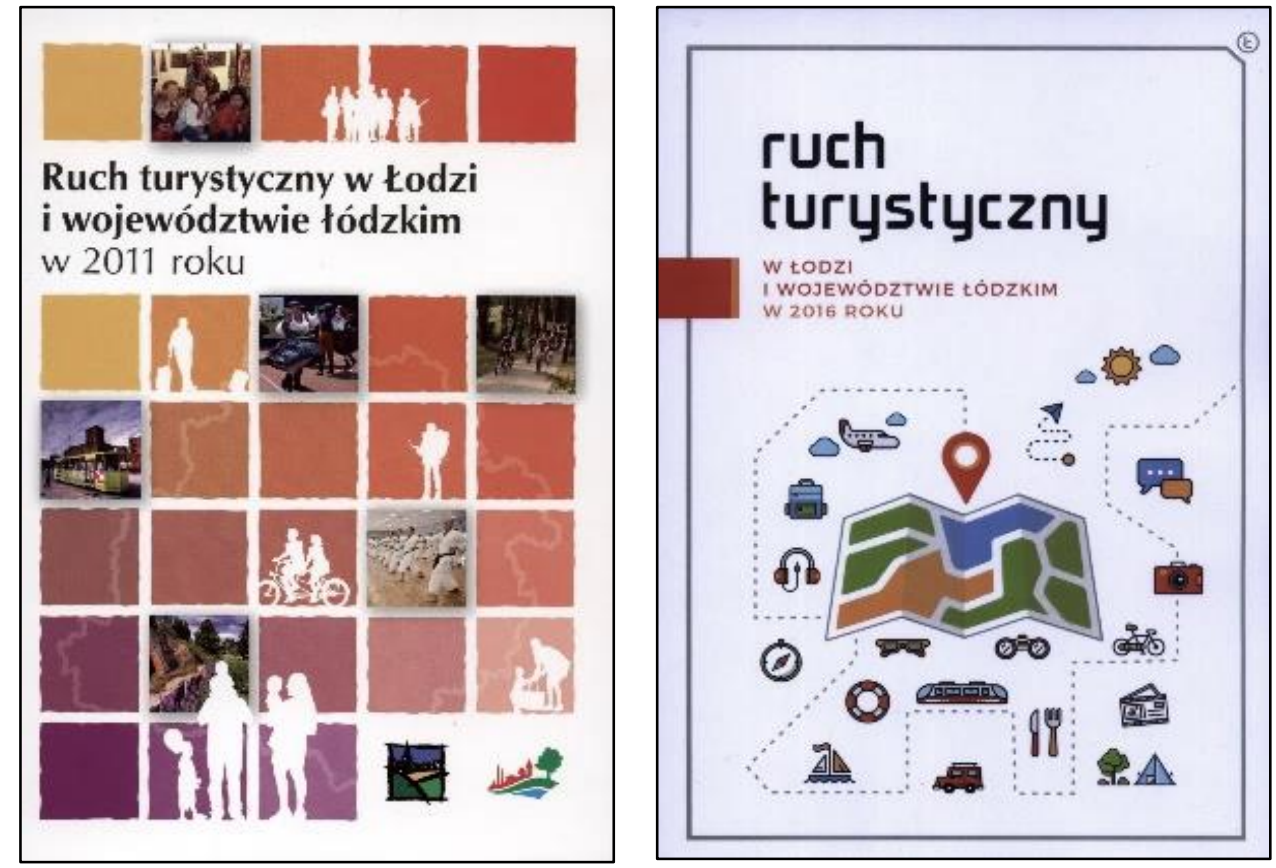

Rys. 16. Raporty badań ruchu turystycznego (archiwum autora)

Reports on tourist traffic research (author's archive)
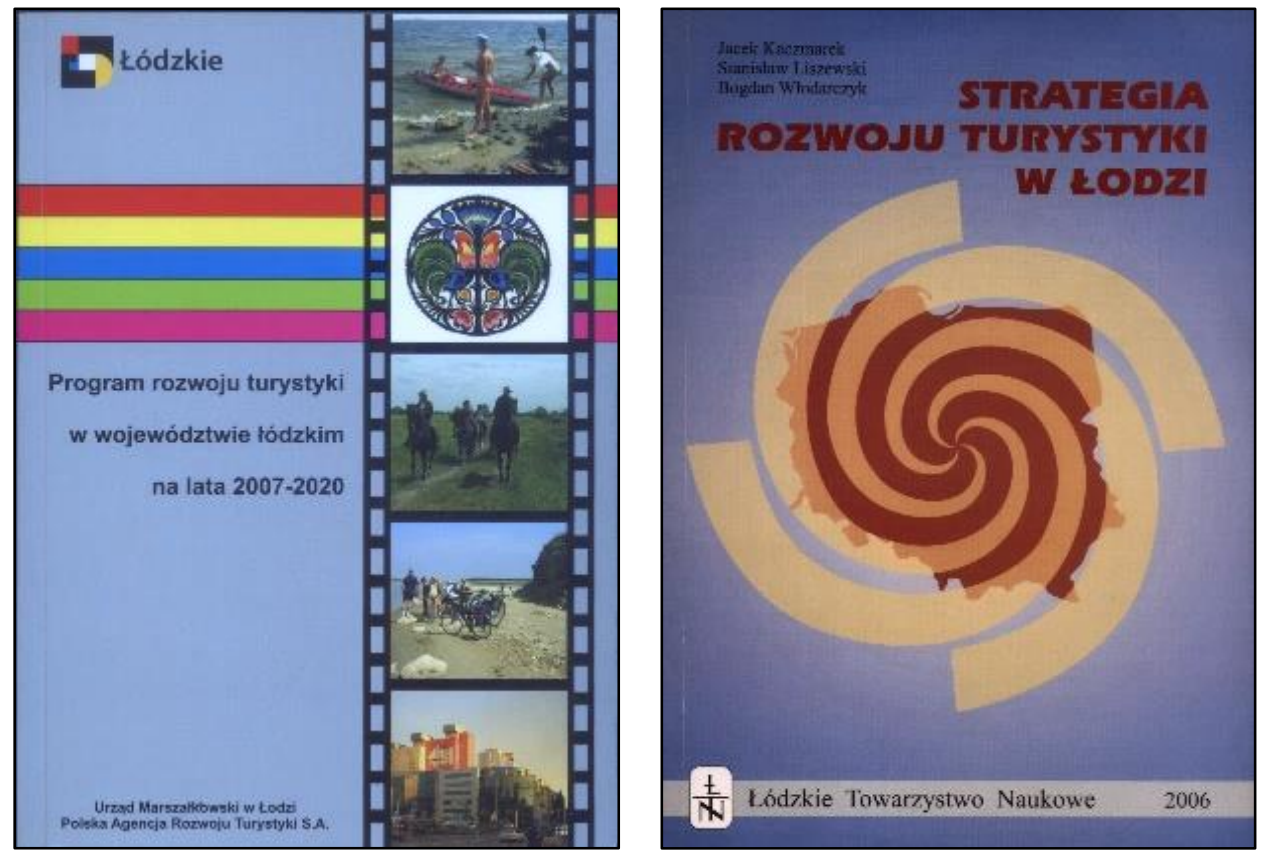

Rys. 17. Dokumenty strategiczne związane z rozwojem turystyki w regionie (archiwum autora)

Strategic documents related to the development of tourism in the region (author's archive)

delimitowanych nie tylko historią Polski (zabory, działania wojenne, przemiany polityczno-społeczno-gospodarcze, wstąpienie do Unii Europejskiej), ale także najważniejszymi wydarzeniami związanymi z turystyką polską (np. powstanie PTK, PTT, PTTK).
Niebagatelną rolę we wspomnianym rozwoju odegrała specyfika regionu położonego na styku wielkich krain historycznych, takich jak Mazowsze, Wielkopolska, Małopolska czy Śląsk, przejściowy charakter środowiska przyrodniczego, czy też żywiołowy rozkwit przemysłu w XIX w. Na podstawie przedstawionych faktów i zarysowanych ten- 
dencji rozwojowych uprawnione wydaje się twierdzenie, że turystyka była jednym, choć być może nie najważniejszym z elementów budowania tożsamości utworzonego w 1919 r. województwa, którego stolica w odróżnieniu od innych nie posiadała, jak pisał Dylik (1971), wyraźnych antenatów.

Zarówno doskonała dostępność komunikacyjna, jak i przygotowywana oferta turystyczna, ukazująca region jako obszar nowoczesny, zróżnicowany i gościnny, skłaniają do pozytywnej oceny aktualnego stanu turystyki oraz perspektyw jej rozwoju w przyszłości.

\section{Literatura}

Baranowski B. 1979. Polska karczma, restauracja, kawiarnia. Ossolineum, Wrocław.

Bonisławski R. 1995. Organizacja turystyki w regionie. W: S. Liszewski (red.) Studium wiedzy o regionie łódzkim. ŁTN, Łódź: 130-133.

Dylik J. 1971. Województwo ze stolicą bez antenatów. Szlakami Nauki 15, ŁTN, Łódź.

Hejneman K. 2009. Miasto Las Kolumna i jego historia. www.gazetalaska.pl

Historia Oddziału Łódzkiego PTK-PTT-PTTK 19092019. 2019. Praca zbiorowa pod red. E. Witkowskiego, E. Korczak, A. Arndta, H. Detynieckiej i R. Mamenasa. Polskie Towarzystwo Turystyczno-Krajoznawcze Oddział Łódzki im. J. Czeraszkiewicza, Łódź.

Kobalczyk A. 2017a. Z letnikami nad Pilicę. Dom Wydawniczy Księży Młyn, Łódź.

Kobalczyk A. 2017b. Sekrety Tomaszowa i Spały. Dom Wydawniczy Księży Młyn, Łódź.

Koter M., Liszewski S., Suliborski A., Wieczorek T. 2002. Łódź i województwo. ŁTN, Łódź.

Liszewski S. 1987. Geneza i rozwój osadnictwa wypoczynkowego w otoczeniu Łodzi. Acta Universitatis Lodziensis, Turyzm 3: 33-54.

Liszewski S. 1991. Spała. Monografia i funkcja miejscowości wypoczynkowej. Turyzm 2: 5-32.

Liszewski S. (red.) 1995. Studium wiedzy o regionie łódzkim. ŁTN, Łódź.

Makowska-Iskierka M. 2011. Procesy urbanizacyjne na terenach turystyczno-wypoczynkowych strefy podmiejskiej Łodzi. ŁTN, Łódź.

Makowska-Iskierka M., Włodarczyk B. 2012. Podmiejskie letniska Łodzi w okresie dwudziestolecia międzywojennego. W: J. Kowalczyk-Anioł, M. Makowska-Iskierka (red.) Turystyka moda na sukces. Seria Warsztaty z Geografii Turyzmu, Wyd. UŁ, Łódź: 83-112.

Matczak A. 1984. Próba wykorzystania analizy morfologicznej do określenia funkcji wypoczynkowej osiedli w strefie podmiejskiej Łodzi. Problemy Turystyki 2: 93-97.
Matczak A. 1986. Budownictwo letniskowe w strefie podmiejskiej Łodzi. Acta Universitatis Lodziensis, Folia Geographica 5:137-166.

Matczak A. 1987. Próba określenia funkcji wypoczynkowej osiedli podmiejskich na przykładzie Kolumny. Acta Universitatis Lodziensis, Turyzm 3: 55-85.

Matczak A. 1994. Rola turystyki i wypoczynku w integracji regonu łódzkiego. W: S. Liszewski (red.) Studium wiedzy o regionie łódzkim. ŁTN, Łódź: 161-188.

Milewska M., Włodarczyk B. 2004. Historia rozwoju hotelarstwa w Łodzi. Turystyka i Hotelarstwo 5: 55-93.

Milewska M., Włodarczyk B. 2005. Historia rozwoju hotelarstwa w regionie łódzkim. Turystyka i Hotelarstwo 7: 133-166.

Słoniewski M. 2012. Prezydencka Spała. MAX s.c. Jolanta i Michał Słoniewscy, Spała.

Słoniewski M., Czestnych S. 2014. Pałac i ludzie. Historia rezydencji myśliwskiej w Spale 18851945. MAX s.c. Jolanta i Michał Słoniewscy, Spała.

Stefański K. 1991. Miasta-ogrody i kolonie letniskowe w strefie podmiejskiej aglomeracji łódzkiej w latach 1925-1939. Zeszyty Naukowe PŁ 553, seria: Budownictwo 42.

Stejskał J. 1992. Podmiejskie rezydencje burżuazji łódzkiej i ich funkcje wypoczynkowe dawniej i obecnie. Turyzm 2(2): 25-44.

Szkup R. 2003. Kształtowanie podmiejskiej przestrzeni wypoczynkowej. Przykład zachodniego sektora strefy podmiejskiej Łodzi. Wyd. UŁ, Łódź.

Śledzińska J. 2009. Polskie Towarzystwo Krajoznawcze i Polskie Towarzystwo Turystyczno-Krajoznawcze w kultywowaniu szlaków polskości na terenie województwa łódzkiego. W: Wzajemne przenikanie kultur $w$ regionie tódzkim a nowe możliwości ruchu krajoznawczego. VI Kongres Krajoznawstwa Polskiego - Olsztyn 2010, Sejmik Przedkongresowy, Łódź-PabianiceZgierz: 37-56.

Wiluś R. 1997. Rozwój funkcji turystycznej w dolinie rzeki Warty na odcinku od Działoszyna do Uniejowa. ŁTN, Łódź.

Wojciechowska J. 1998. Kolonizacja turystyczna terenów nadpilicznych. ŁTN, Łódź.

Wojciechowska J. 2018. Agroturystyka. Signum turystyki i obszarów wiejskich. Polskie Wydawnictwo Ekonomiczne, Warszawa.

Włodarczyk B. 1999. Przemiany form aktywności turystycznej - przykład krawędzi Wyżyny Łódzkiej. ŁTN, Łódź.

Włodarczyk B. 2009. Przestrzeń turystyczna - istota koncepcje, determinanty rozwoju. Wyd. UŁ, Łódź. 


\section{Summary}

The article presents the characteristics of tourism in the Łódź region in individual periods of tourism development in Poland. The author focuses on the last 100 years, when, according to the administrative division of the country, the area in question was referred to as Łódź Voivodeship (Łódź Province). Tourism development has been divided into several periods, described by indicating their characteristic features.

Tourism development in the Łódź region, understood as undertaking tourist activity as well as founding tourism institutions, can be divided into several characteristic periods, delimited by the history of Poland (partitions; wars; political, social and economic transformations; joining the European Union) as well as major events connected with Polish tourism (e.g. the founding of the PTK - the Polish Sightseeing Association, the PTT - the Polish Tourism Association, the PTTK - the Polish Tourism and Sightseeing Association).

A significant role in the tourism development of the Łódź region was played by its particular character, including its location on the border between vast historical lands such as Masovia, Greater Poland, Lesser Poland and Silesia, the temporary character of the natural environment, and the rapid growth of industry in the 19th century. Based on facts and visible development trends, it seems justified to claim that tourism was a major (though perhaps not the most important) factor in building the identity of the province, which was established in 1919 and whose capital city did not have clearly defined predecessors, unlike other provinces (Dylik 1971).

The ideal accessibility by transport and the tourist offer, which presents the region as a modern, varied and hospitable area, encourage a positive evaluation, not only of the current state of tourism but also of its future development prospects.

Taking into account the development of Polish tourism, as well as the specific location and history of Central Poland, tourist activity in Łódź Province can be divided into several characteristic periods:

Before the end of the $18^{\text {th }}$ century. This period was characterised by minimal tourist activity. Tourist-recreational travel included Polish rulers' hunting expeditions or noblemen's journeys to state and local parliament assemblies, high church officials' recreational trips and merchants' business travels. The evidence of those trips are the few elements of material heritage that have survived (e.g. summer palaces in Skierniewice or Wolbórz).
The $19^{\text {th }}$ and early $20^{\text {th }}$ century, before 1918 . This was mostly the time of partitions and the limitations they brought. Tourist activity started to develop in the suburban areas of larger towns (summer resorts - Głowno, Kolumna, Tuszyn) and areas with medicinal resources (health resorts) such as fresh air and curative mineral waters (Inowłódz). At that time, the first tourism organisations and associations started to appear (e.g. the Polish Tourism Association), as did tourism museums (Łowicz, Piotrków Trybunalski) and tourist guidebooks.

The interwar period and World War II. This was a time of further growth of suburban summer resorts, the garden-city concept (Sokolniki, Kolumna, Tuszyn), as well as mass tourist-patriotic events (e.g. Presidential Harvest Holiday, the Polish Scouts Jubilee Convention in Spała). It was also the beginning of organised recreation for children and adolescents (YMCA camps, Polish Scouts Union, "Społem" summer holidays for children). World War II limited or completely stopped the development of tourist activity in the region.

The socialist period 1945-1989. These were the years of the nationalisation and socialisation of tourism institutions. The majority of the tourism events organised at that time were society-oriented and financed by the state or by Łódź enterprises, which owned numerous holiday resorts all over the country. It was also a time when the Polish Tourism and Sightseeing Association was founded and rapidly developed, promoting active and qualified tourism. Tourism in the Łódź region rediscovered rural areas, which showed in the appearance of the first agritourism farms.

After 1989. This time was divided into two sub-periods: before 2000 and after. First, due to the transformation of the political-economic system, it was possible to observe the decline of the state and state company tourist infrastructure, as well as the intense activity of new, commercial institutions such as private travel agencies and private accommodation and gastronomic facilities. During the latter period, tourism development was more related to raising quality and verifying the activity of existing institutions. At that time, Łódź and its region gained facilities belonging to international hotel chains and systems, and foreign tour-operators representing world brands started or increased their activity.

Currently, very good accessibility by transport (motorways, fast roads), as well as the tourist offer, which presents the region as a modern, varied and hospitable area, encourage a positive evaluation of the present state of tourism and good future development prospects. 
